\title{
One-Pot Strategy for Symmetrical and Unsymmetrical BOIMPY Fluorophores
}

\author{
Tyll Freese ${ }^{1}$, Lukas J. Patalag ${ }^{1}$, J. Luca Merz ${ }^{1}$, Peter G. Jones ${ }^{2}$ and
}

Daniel B. Werz ${ }^{1, *}$

\section{Corresponding Author}

Daniel B. Werz - Email: d.werz@ tu-braunschweig.de; orcid.org/0000-0002-3973-2212

${ }^{1}$ Technische Universität Braunschweig, Institute of Organic Chemistry, 38106 Braunschweig, Germany ${ }^{2}$ Technische Universität Braunschweig, Institute of Inorganic and Analytical Chemistry,
38106 Braunschweig, Germany

Supporting Information

Table of Contents

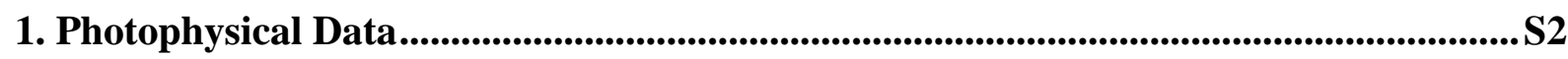

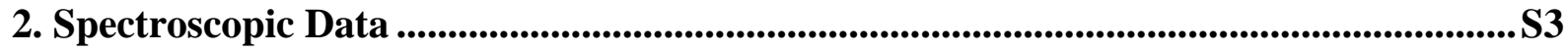

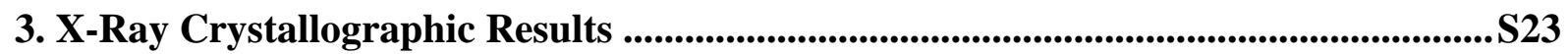

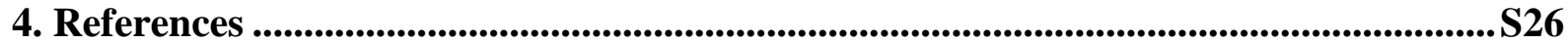




\section{Photophysical Data}

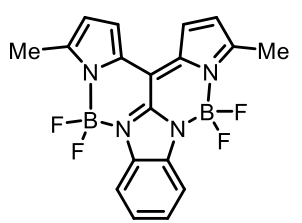

$5 a^{[a]}$

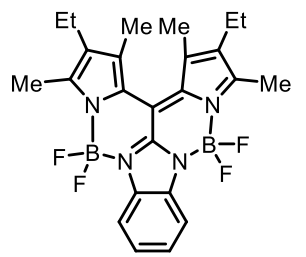

$5 f$

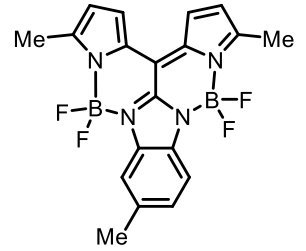

$5 b$

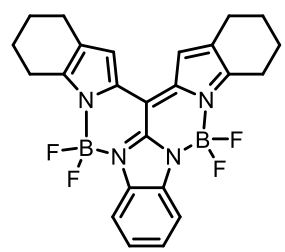

$5 g^{[a]}$

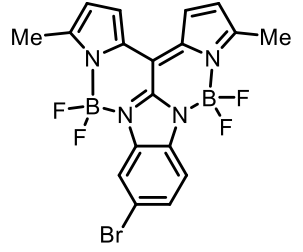

$5 c^{[a]}$

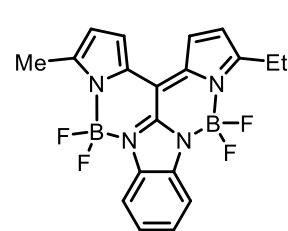

$8 a$

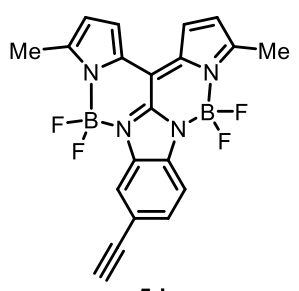

$5 d$

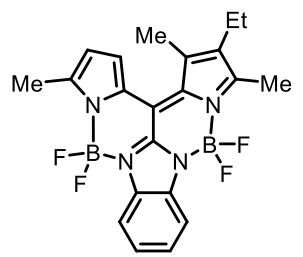

$8 b$

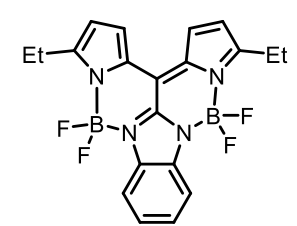

$5 e^{[a]}$

Figure S1. Compound overview. [a] Compounds are known from literature. ${ }^{[1]}$

Table S1. Photophysical data.

\begin{tabular}{|c|c|c|c|c|c|c|}
\hline & $\lambda_{\max }^{\mathrm{A}}[\mathrm{nm}]$ & $\lambda_{\max }^{\mathrm{F}}[\mathbf{n m}]$ & $\varepsilon\left[10^{3} \mathrm{M}^{-1} \mathrm{~cm}^{-1}\right]^{[b]}$ & $\Delta \tilde{\boldsymbol{v}}\left[\mathbf{c m}^{-1}\right]^{[\mathrm{c}]}$ & $\Phi_{F}(\mathbf{r t})^{[d]}$ & $\tau_{F}[\mathrm{~ns}]^{[\mathrm{e}]}$ \\
\hline $5 \mathbf{a}$ & $596(594)$ & $605(602)$ & $72.3(70.5)$ & $250(224)$ & $0.72(0.71)$ & 6.68 \\
\hline $5 b$ & $596(594)$ & $605(603)$ & $80.1(74.5)$ & $250(251)$ & $0.73(0.73)$ & 6.58 \\
\hline $5 c$ & $600(598)$ & $609(607)$ & $81.0(75.5)$ & $246(248)$ & $0.57(0.55)$ & 6.42 \\
\hline $5 d$ & $600(598)$ & $609(608)$ & $75.9(70.9)$ & $246(275)$ & $0.72(0.63)$ & 6.47 \\
\hline $5 e$ & $599(596)$ & $609(606)$ & $82.4(80.5)$ & $274(277)$ & $0.73(0.67)$ & 6.49 \\
\hline $5 f$ & $589(586)$ & $618(612)$ & $60.3(54.0)$ & $797(725)$ & $0.08(0.08)$ & 1.12 \\
\hline $5 g$ & $622(619)$ & $629(625)$ & $115.5(103.8)$ & $179(155)$ & $0.64(0.58)$ & 5.81 \\
\hline $\mathbf{8 a}$ & $597(595)$ & $607(604)$ & $77.3(74.8)$ & $276(250)$ & $0.70(0.68)$ & 6.50 \\
\hline $8 b$ & $584(581)$ & $605(603)$ & $66.6(62.2)$ & $594(628)$ & $0.10(0.09)$ & 1.04 \\
\hline
\end{tabular}

[a] First value in DCM, second value in THF (brackets), $\lambda_{\max }^{\mathrm{A}}=$ absorption wavelength, $\lambda_{\max }^{\mathrm{F}}=$ fluorescence wavelength. [b] Attenuation coefficient. [c] Stokes' shift. [d] Absolute fluorescence quantum yield. [e] Fluorescence lifetime, experimentally determined. 


\section{Spectroscopic Data}

Due to bad solubility in most NMR solvents but DMSO, the ${ }^{1} \mathrm{H}$ - and ${ }^{13} \mathrm{C}-\mathrm{NMR}$ spectra are given in DMSO-d6. Problematic though is the fact that DMSO mediates a slow decarboxylation of benzimidazole carboxylic acids. Therefore, we firstly provide the ${ }^{1} \mathrm{H}-\mathrm{NMR}$ spectrum measured in $\mathrm{CD}_{3} \mathrm{OD}$ (Figure S2) to verify the purity of $\mathbf{1 d}$ and secondly the ${ }^{1} \mathrm{H}$ - and ${ }^{13} \mathrm{C}-\mathrm{NMR}$ spectra for the respective NMR shifts.

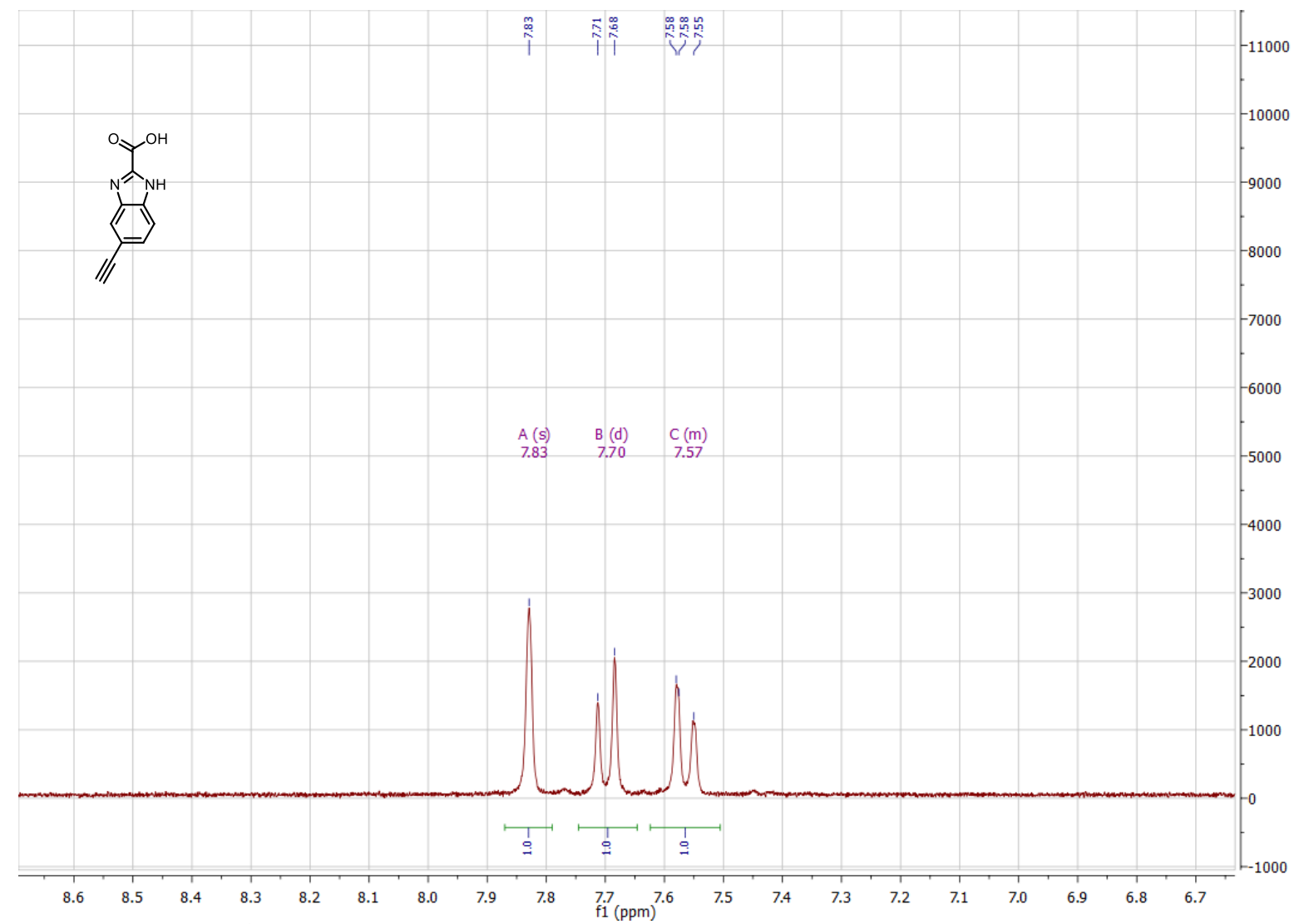

Figure S2. Cutout of ${ }^{1} \mathrm{H}$ NMR $\left(\mathrm{CD}_{3} \mathrm{OD}, 300 \mathrm{MHz}\right)$ spectrum of $\mathbf{1 d}$ to verify purity. 


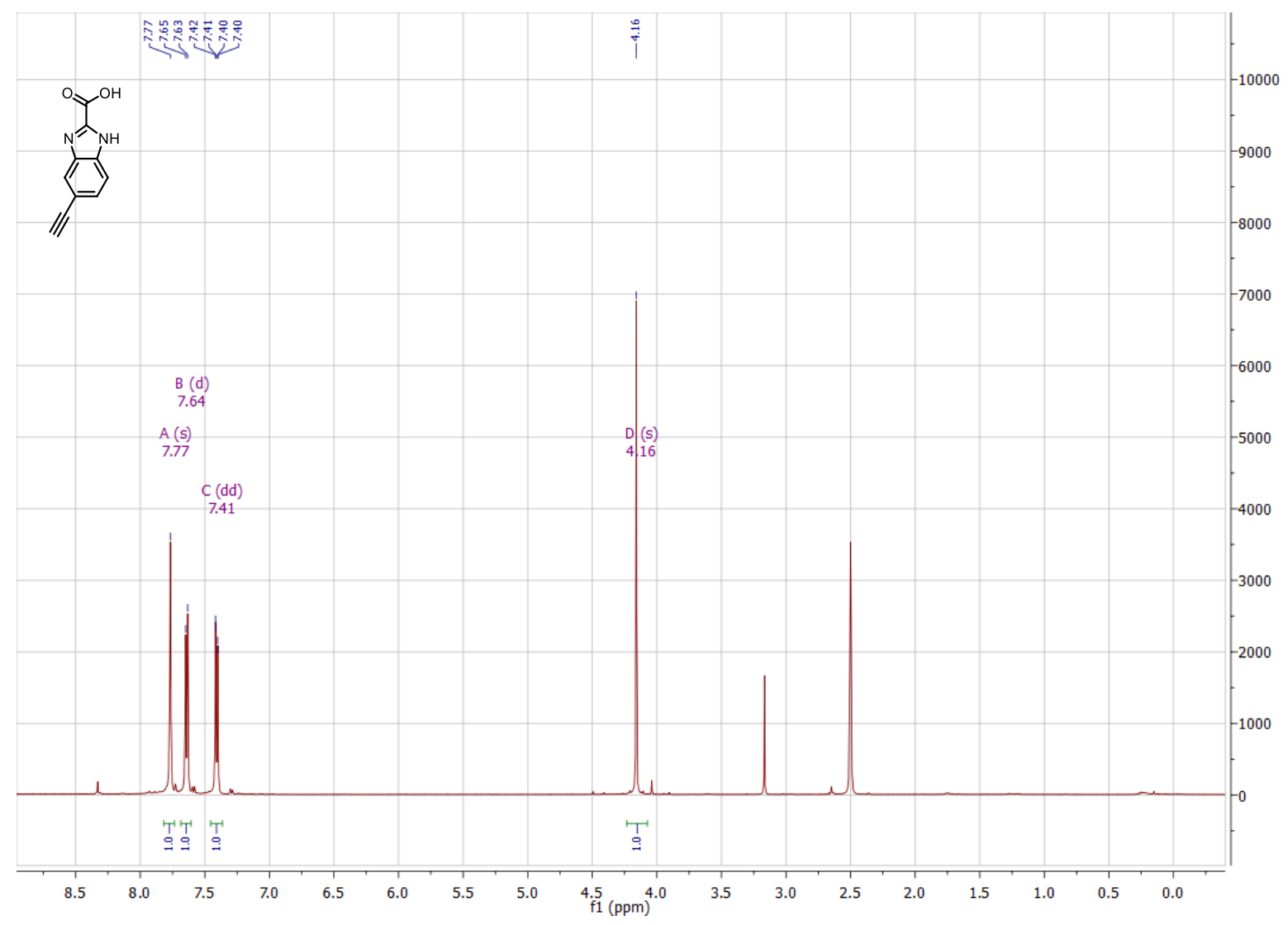

Figure S3. ${ }^{1} \mathrm{H}$ NMR (DMSO- $d_{6}, 500 \mathrm{MHz}$ ) spectrum of $1 \mathrm{~d}$ containing decomposition by-product induced by DMSO.

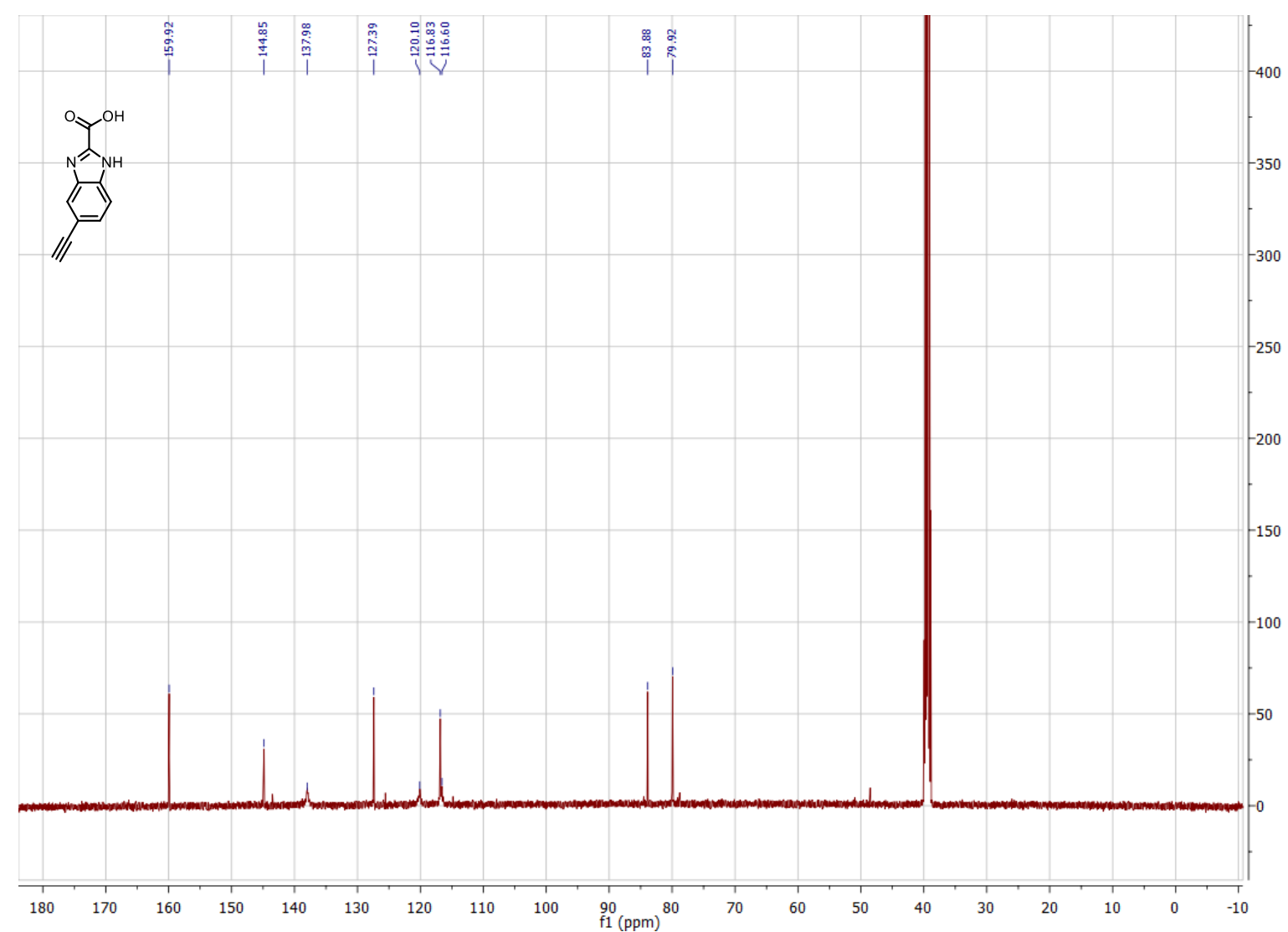

Figure S4. ${ }^{13} \mathrm{C}\left\{{ }^{1} \mathrm{H}\right\}$ NMR (DMSO- $d_{6}, 125 \mathrm{MHz}$ ) spectrum of $\mathbf{1 d}$ containing decomposition by-product induced by DMSO. 


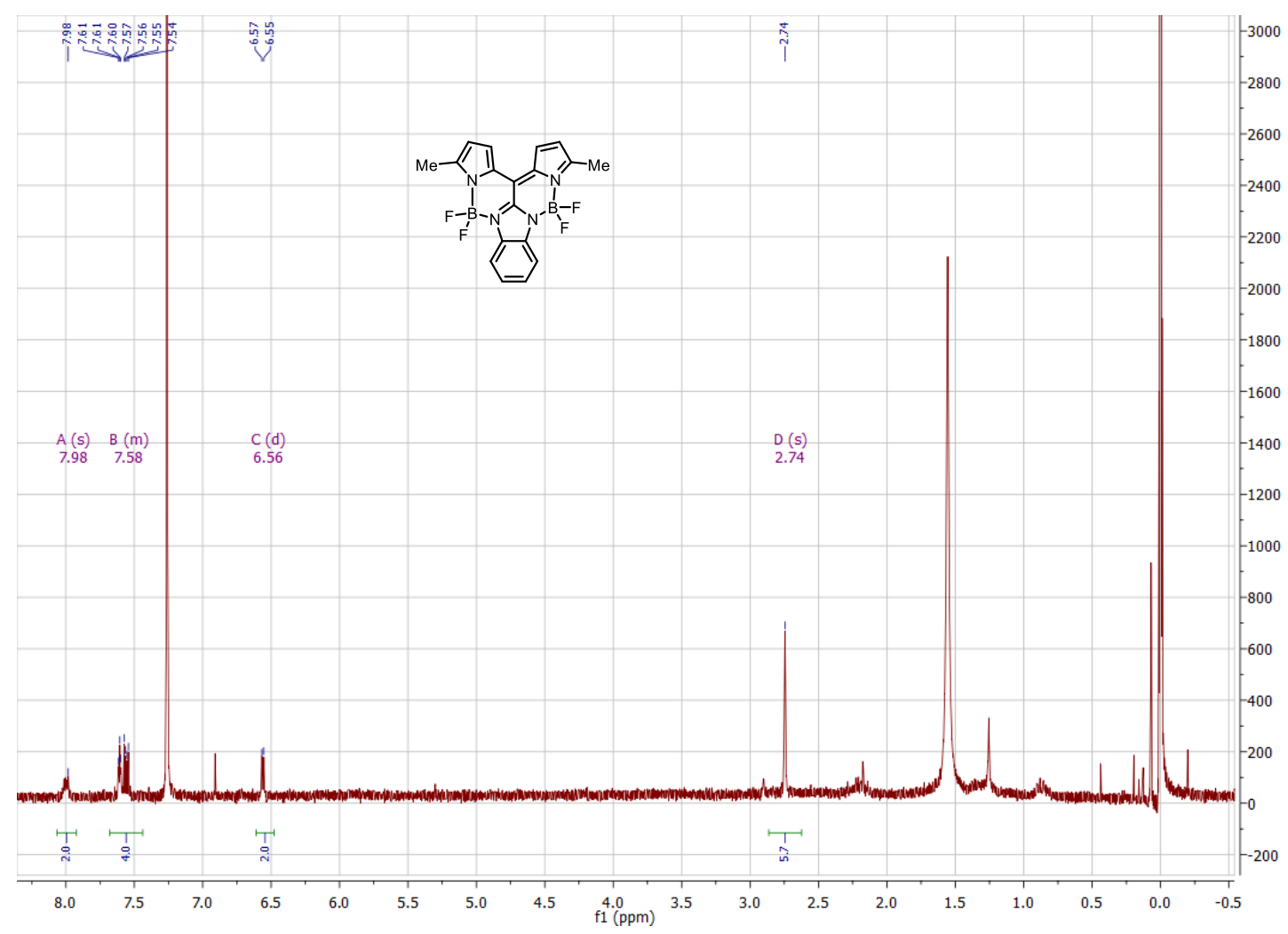

Figure S5. ${ }^{1} \mathrm{H}$ NMR $\left(\mathrm{CDCl}_{3}, 300 \mathrm{MHz}\right)$ spectrum of 5a. Solubility is very low. Analytic data is in agreement with the literature. ${ }^{[1]}$

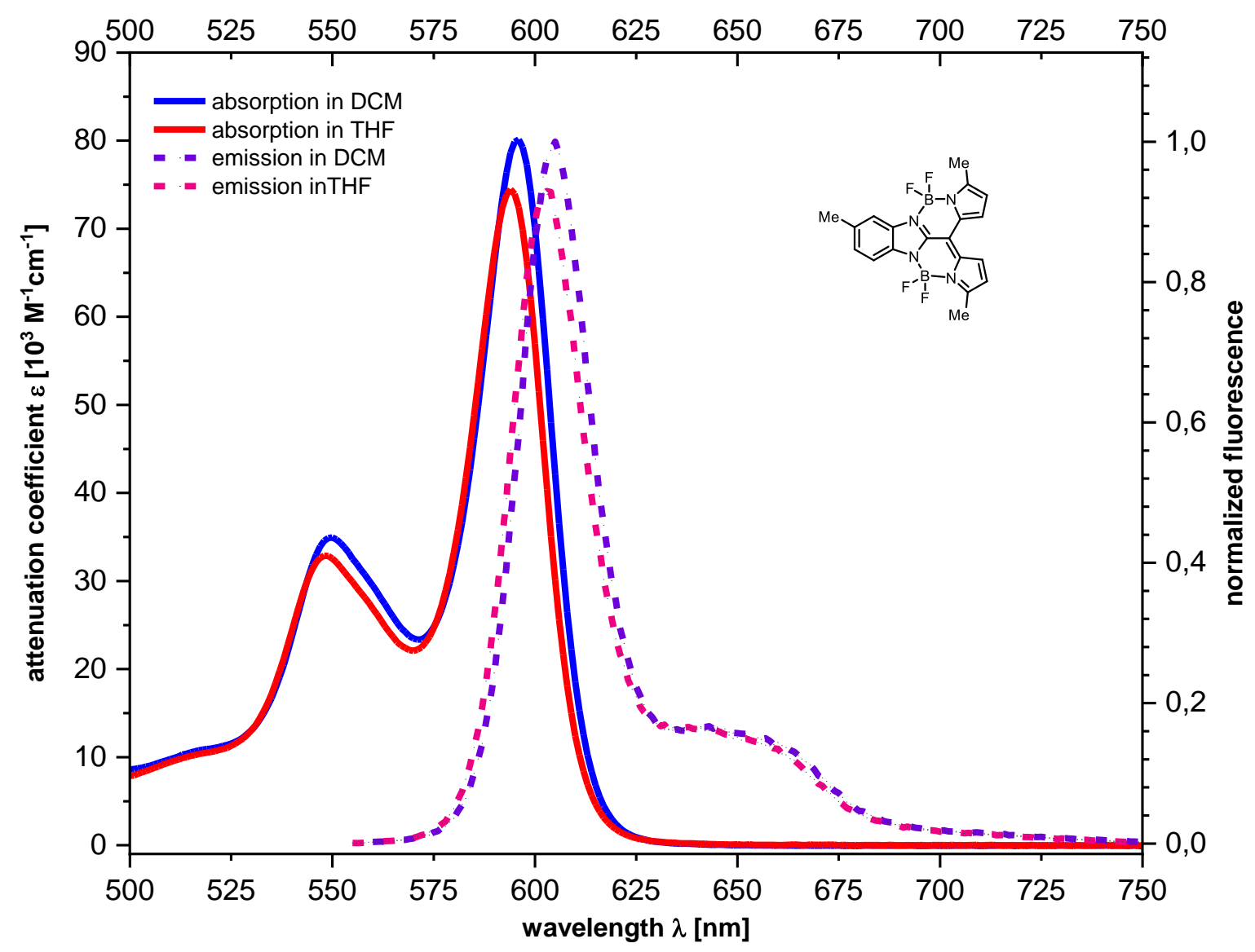

Figure S6. UV-Vis and normalized fluorescence spectra of $\mathbf{5 b}$ in DCM and THF at room temperature. 


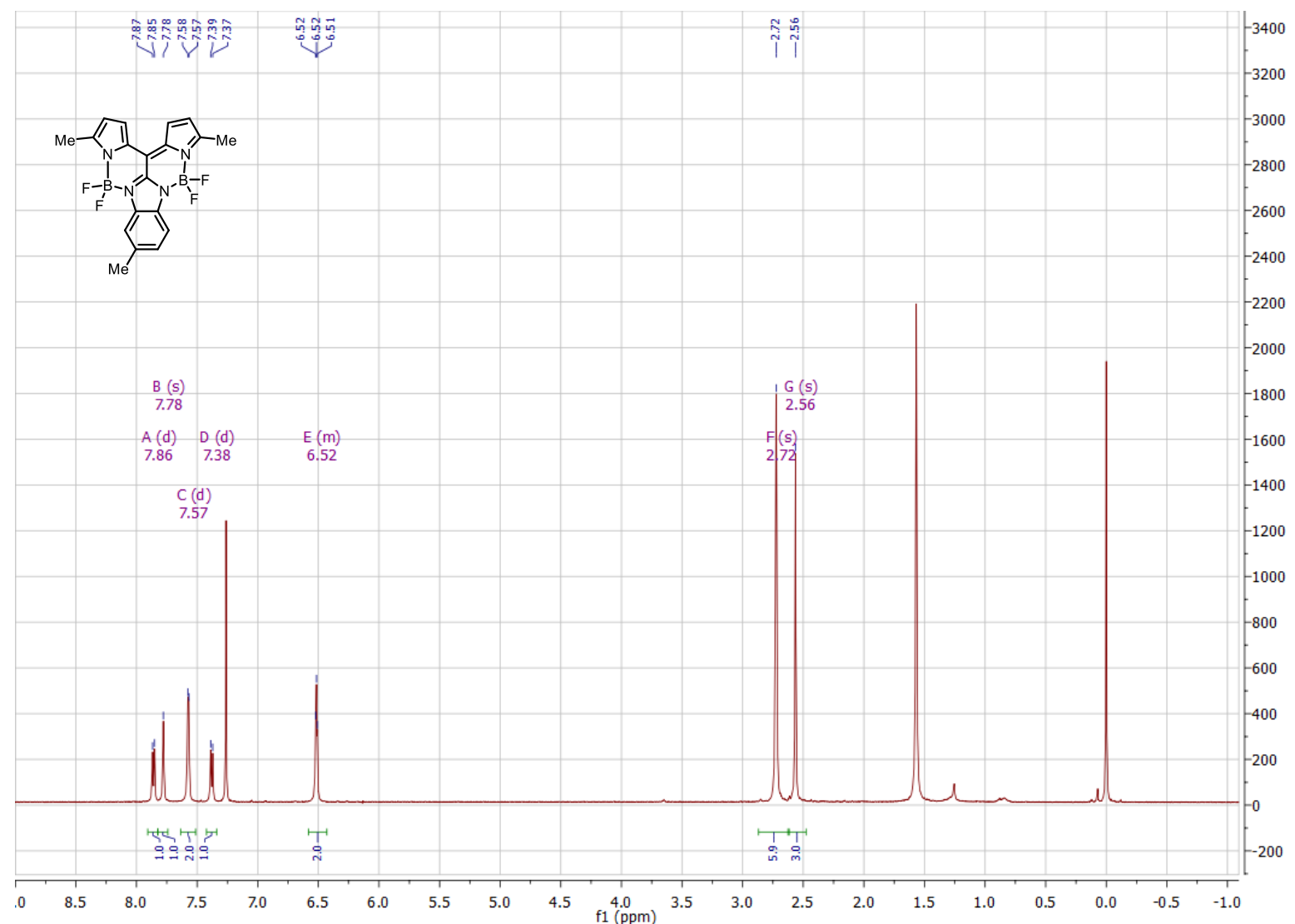

Figure $\mathbf{S 7} .{ }^{1} \mathrm{H} \mathrm{NMR}\left(\mathrm{CDCl}_{3}, 500 \mathrm{MHz}\right)$ spectrum of $\mathbf{5 b}$.

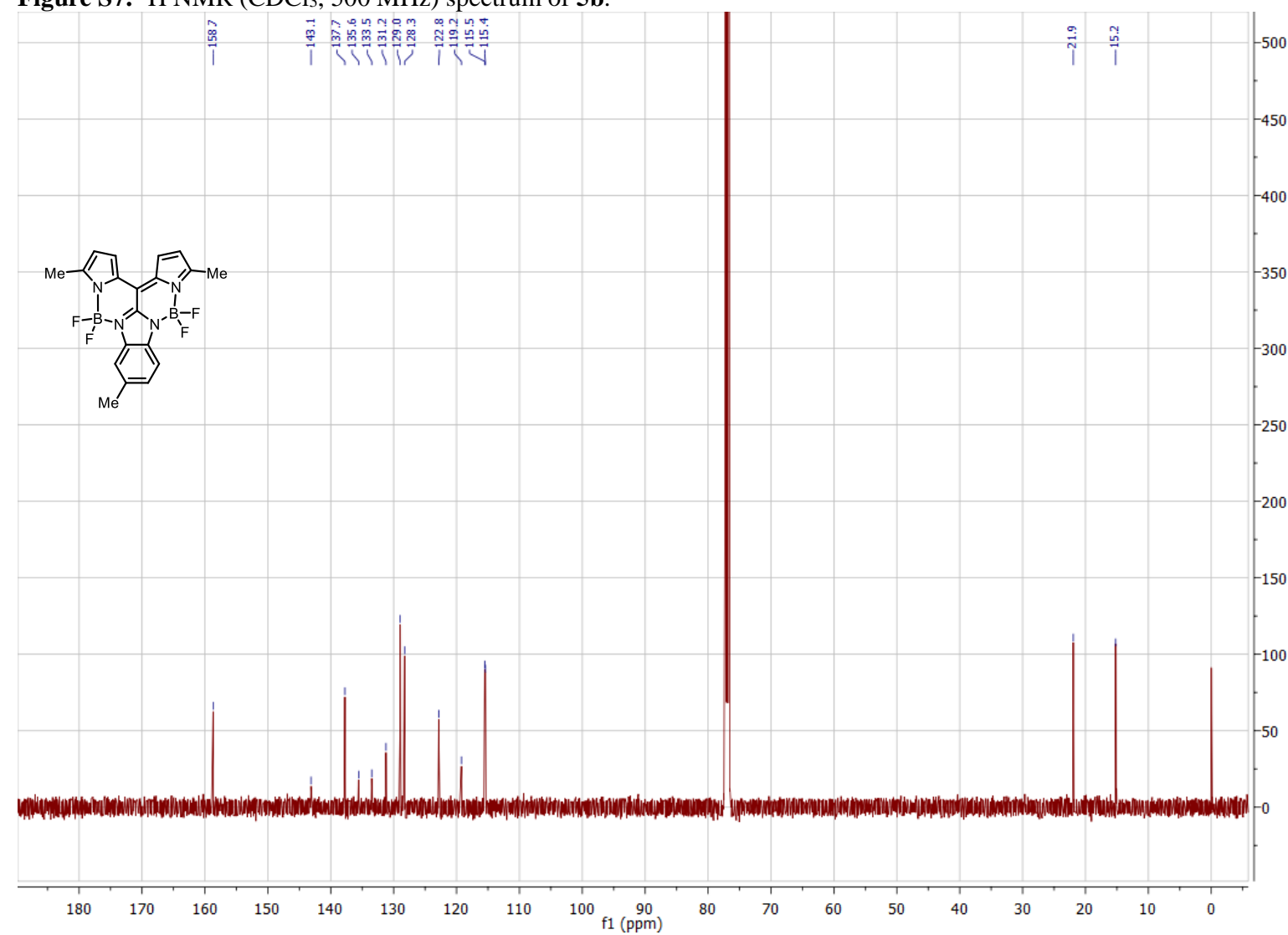

Figure S8. ${ }^{13} \mathrm{C}\left\{{ }^{1} \mathrm{H}\right\} \mathrm{NMR}\left(\mathrm{CDCl}_{3}, 125 \mathrm{MHz}\right)$ spectrum of $\mathbf{5 b}$. 


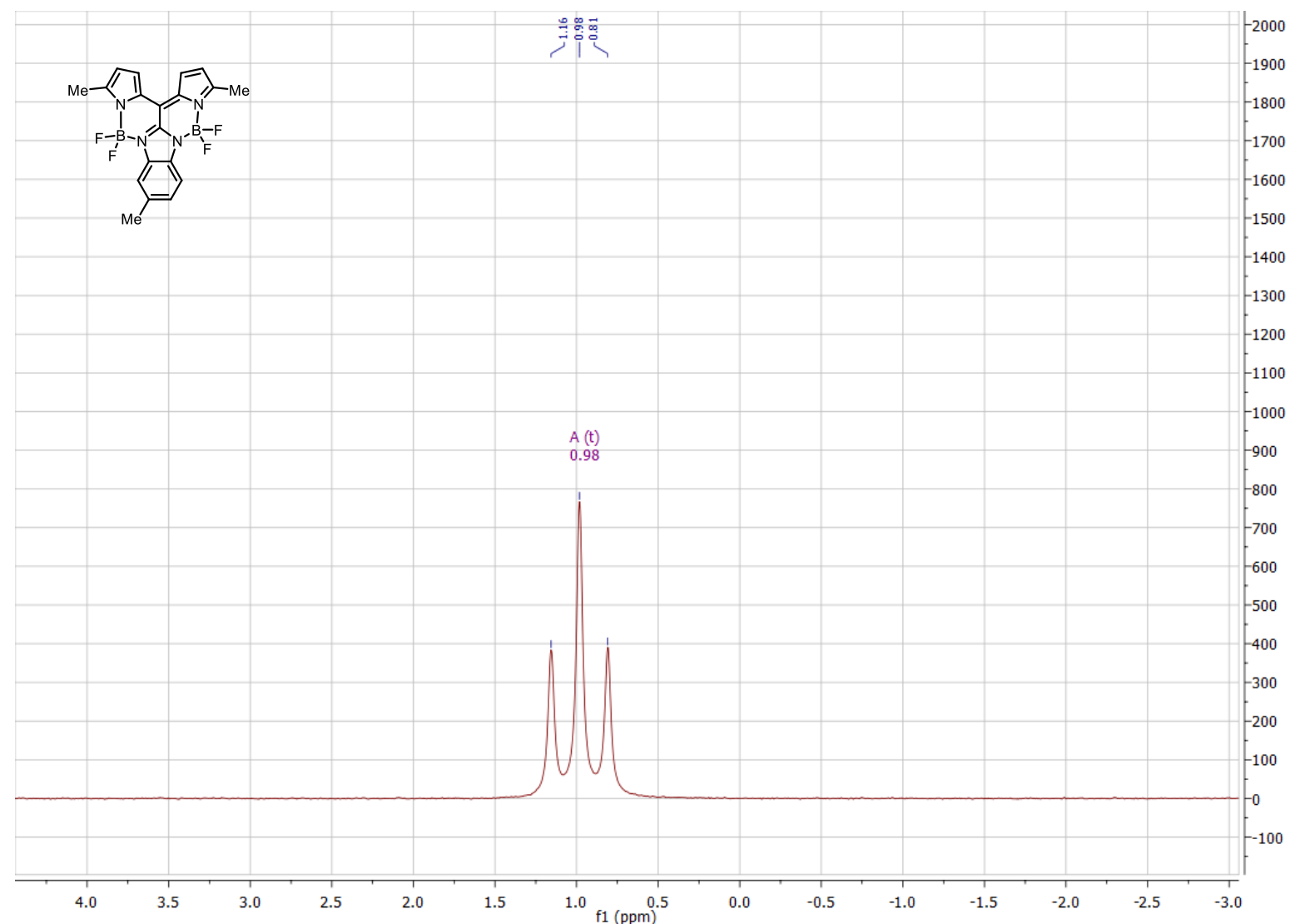

Figure S9. ${ }^{11} \mathrm{~B} \mathrm{NMR}\left(\mathrm{CDCl}_{3}, 161 \mathrm{MHz}\right)$ spectrum of $\mathbf{5 b}$.

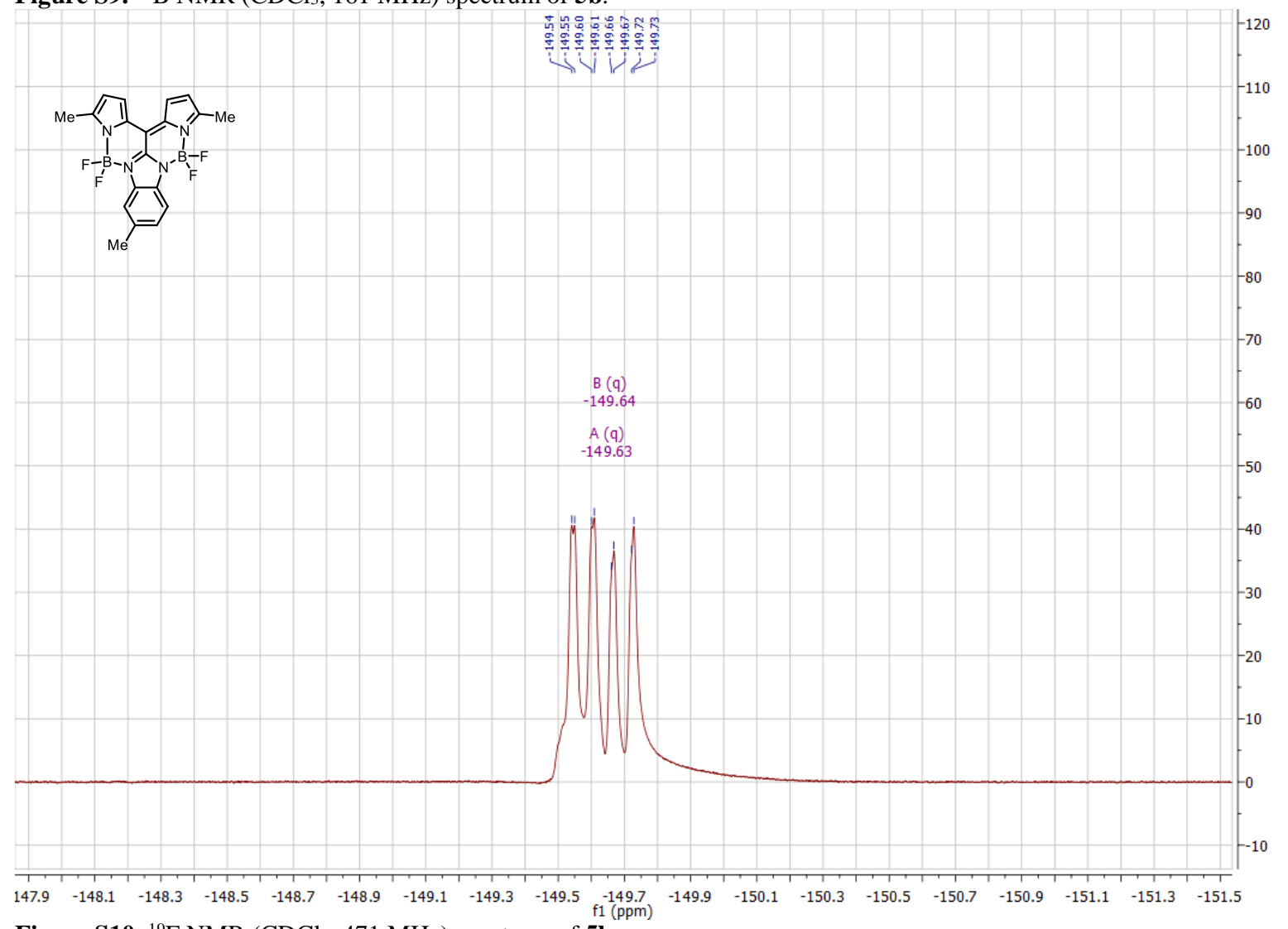

Figure S10. ${ }^{19} \mathrm{~F}$ NMR $\left(\mathrm{CDCl}_{3}, 471 \mathrm{MHz}\right)$ spectrum of $\mathbf{5 b}$. 


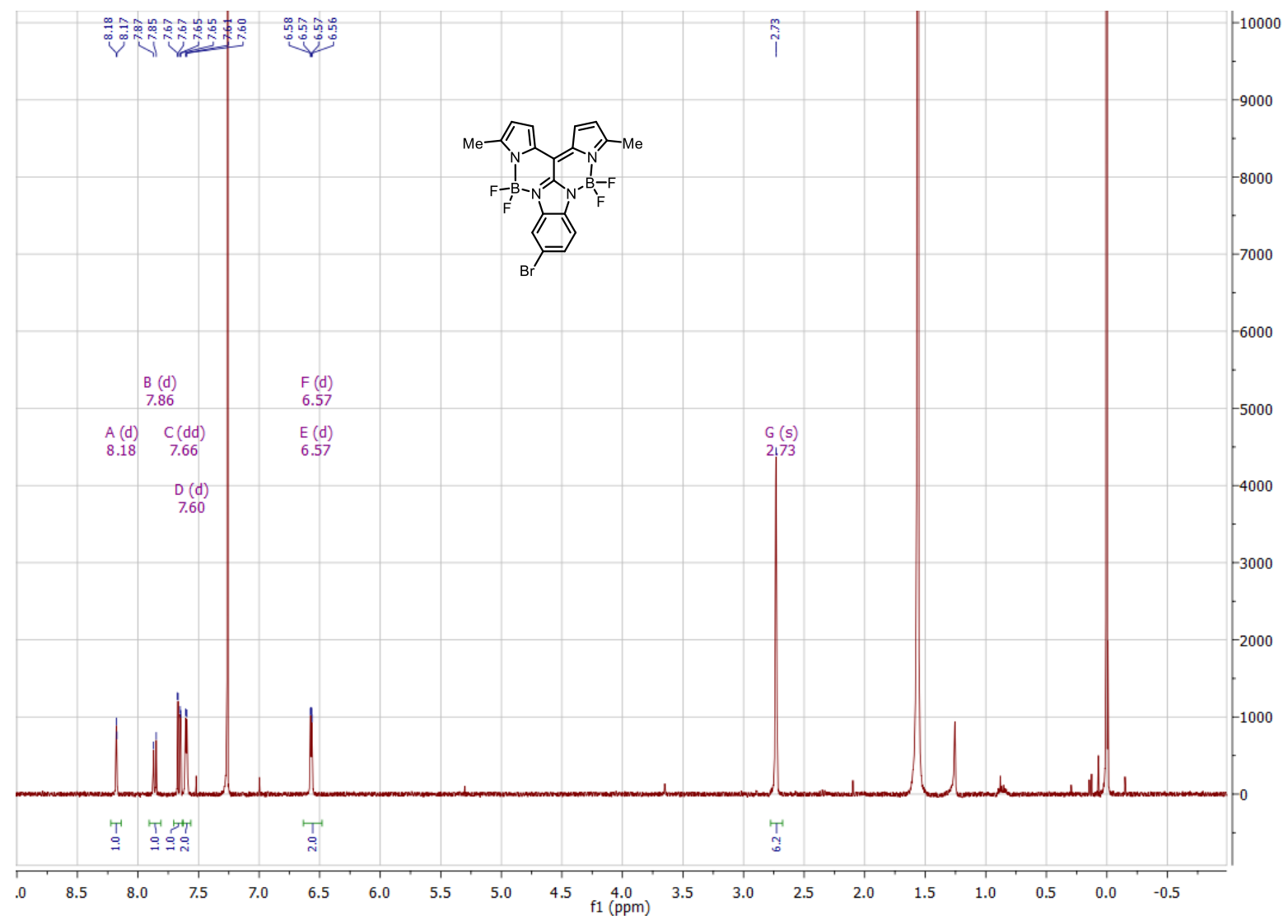

Figure S11. ${ }^{1} \mathrm{H} \mathrm{NMR}\left(\mathrm{CDCl}_{3}, 500 \mathrm{MHz}\right)$ spectrum of $\mathbf{5 c}$. Analytic data is in agreement with the literature. ${ }^{[1]}$

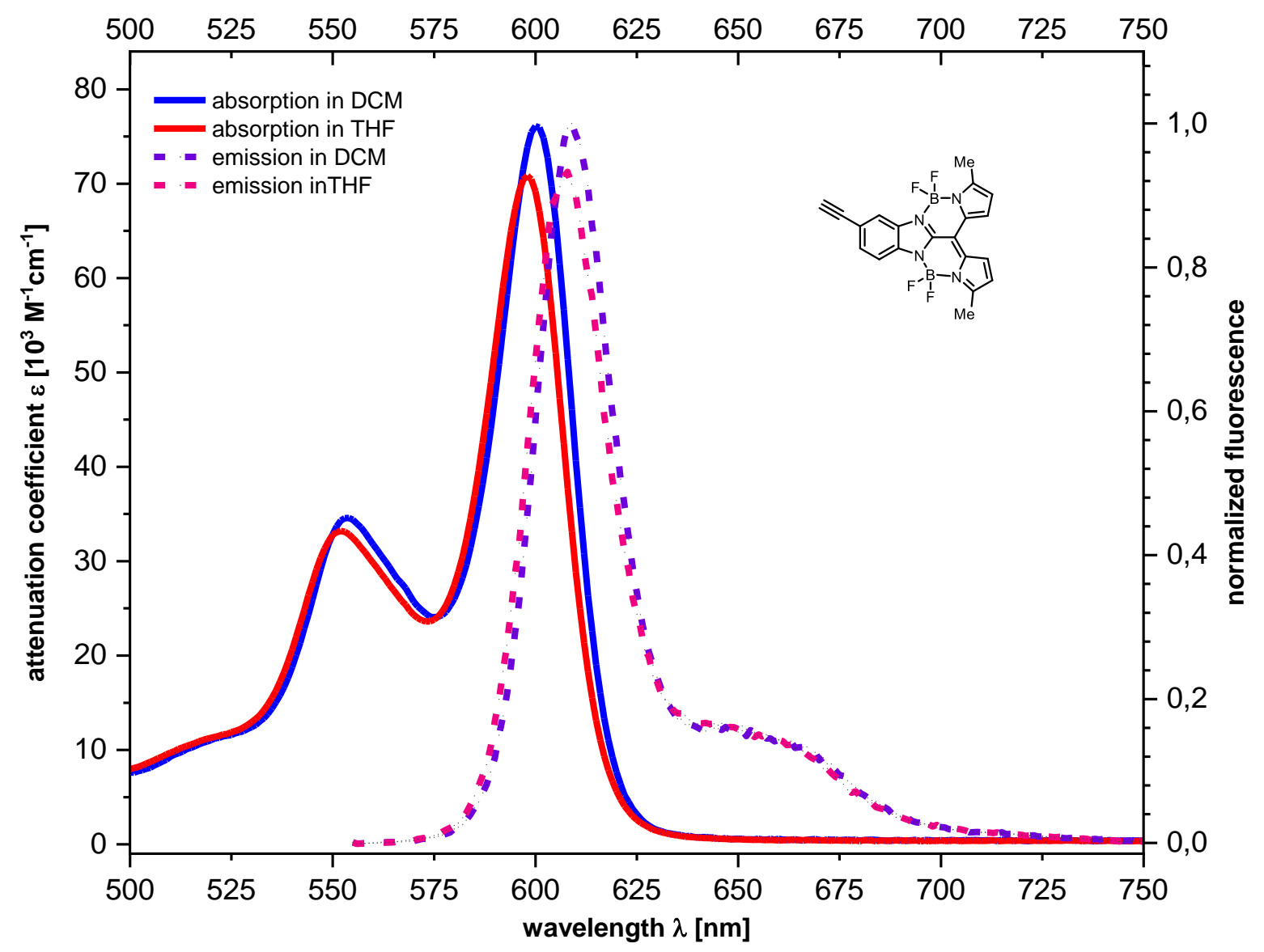

Figure S12. UV-Vis and normalized fluorescence spectra of $\mathbf{5 d}$ in DCM and THF at room temperature. 


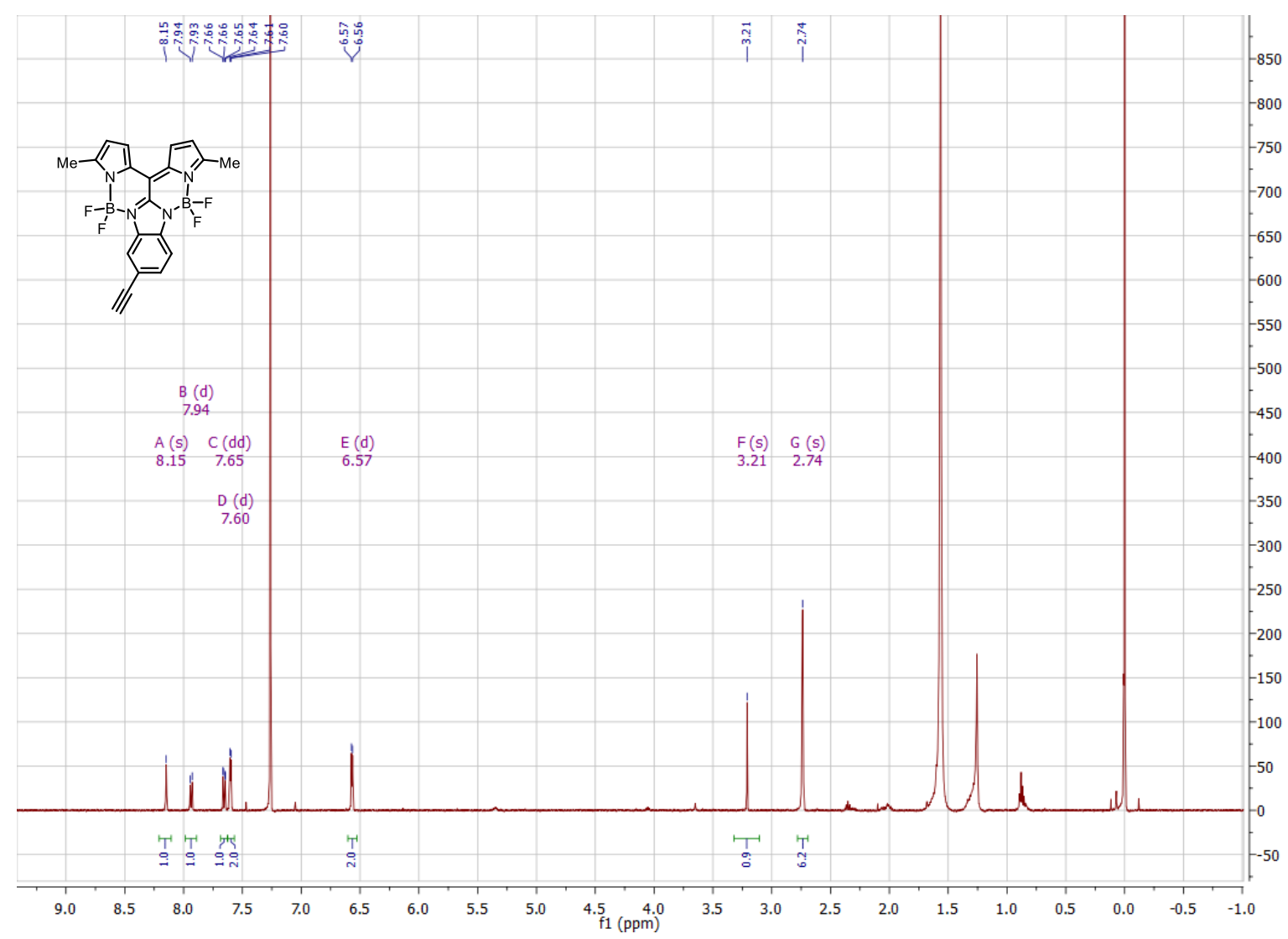

Figure S13. ${ }^{1} \mathrm{H}$ NMR $\left(\mathrm{CDCl}_{3}, 500 \mathrm{MHz}\right)$ spectrum of $\mathbf{5 d}$.

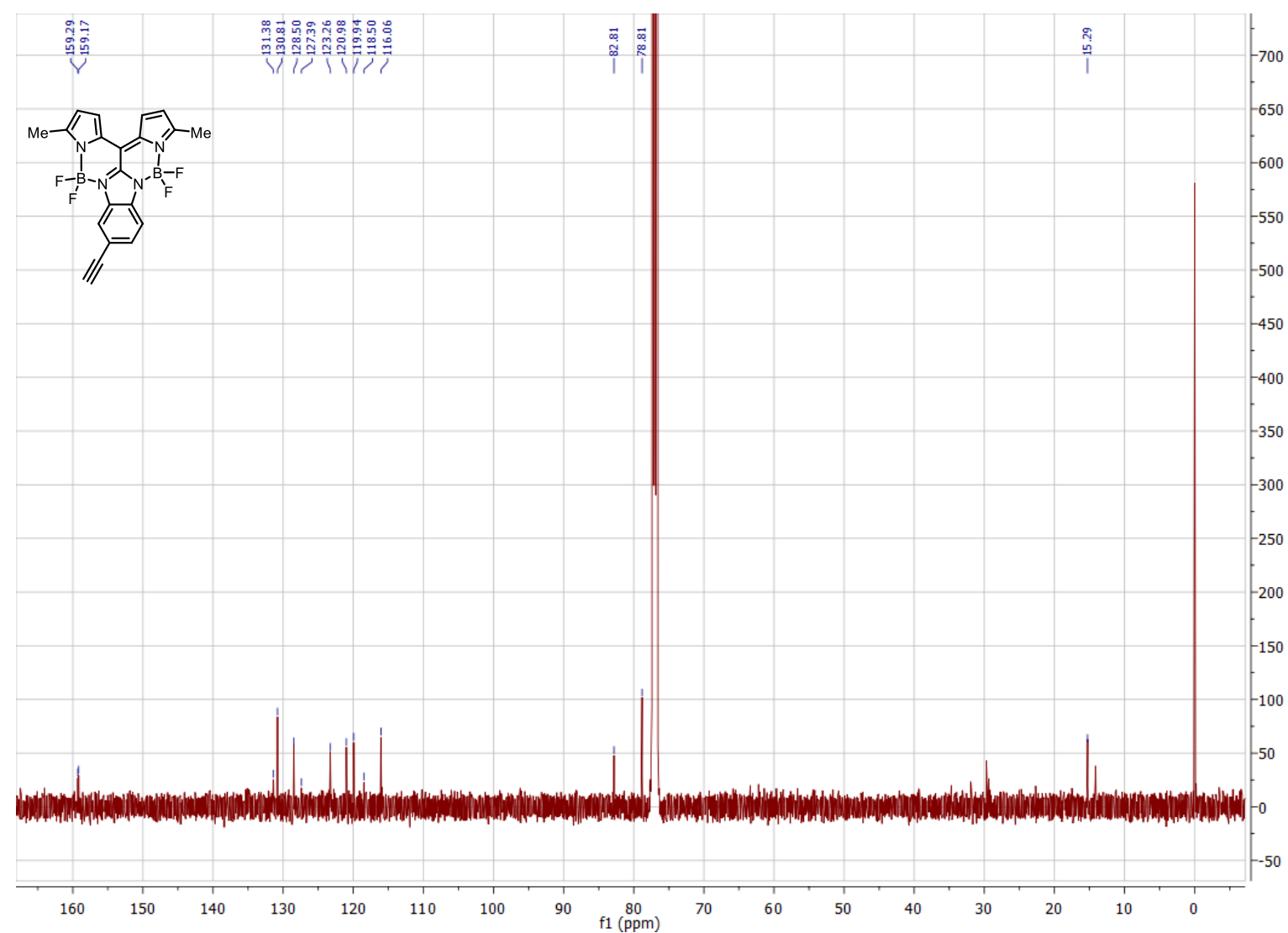

Figure S14. ${ }^{13} \mathrm{C}\left\{{ }^{1} \mathrm{H}\right\}$ NMR $\left(\mathrm{CDCl}_{3}, 125 \mathrm{MHz}\right)$ spectrum of $\mathbf{5 d}$. 


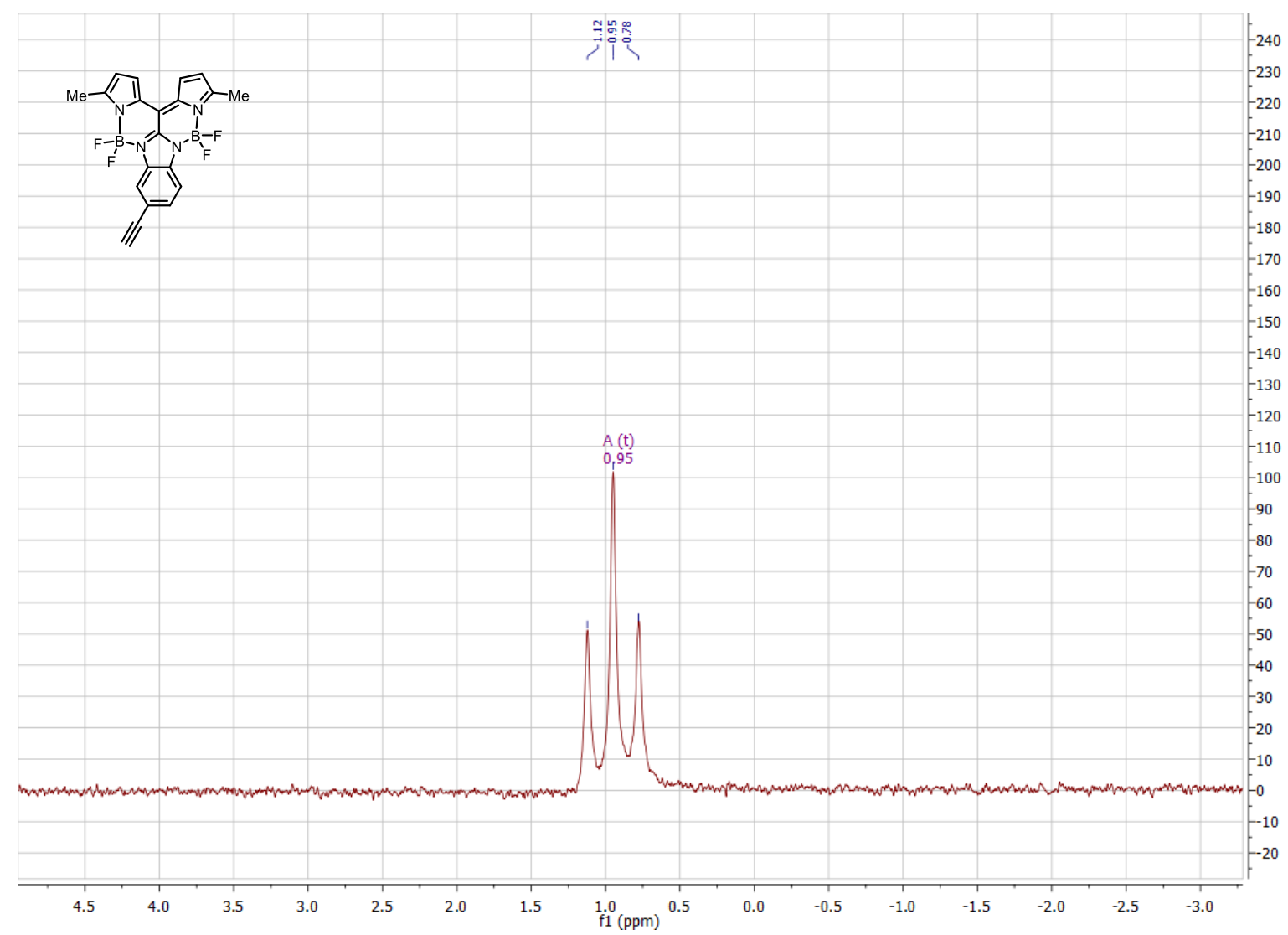

Figure S15. ${ }^{11} \mathrm{~B}$ NMR $\left(\mathrm{CDCl}_{3}, 161 \mathrm{MHz}\right)$ spectrum of $\mathbf{5 d}$.

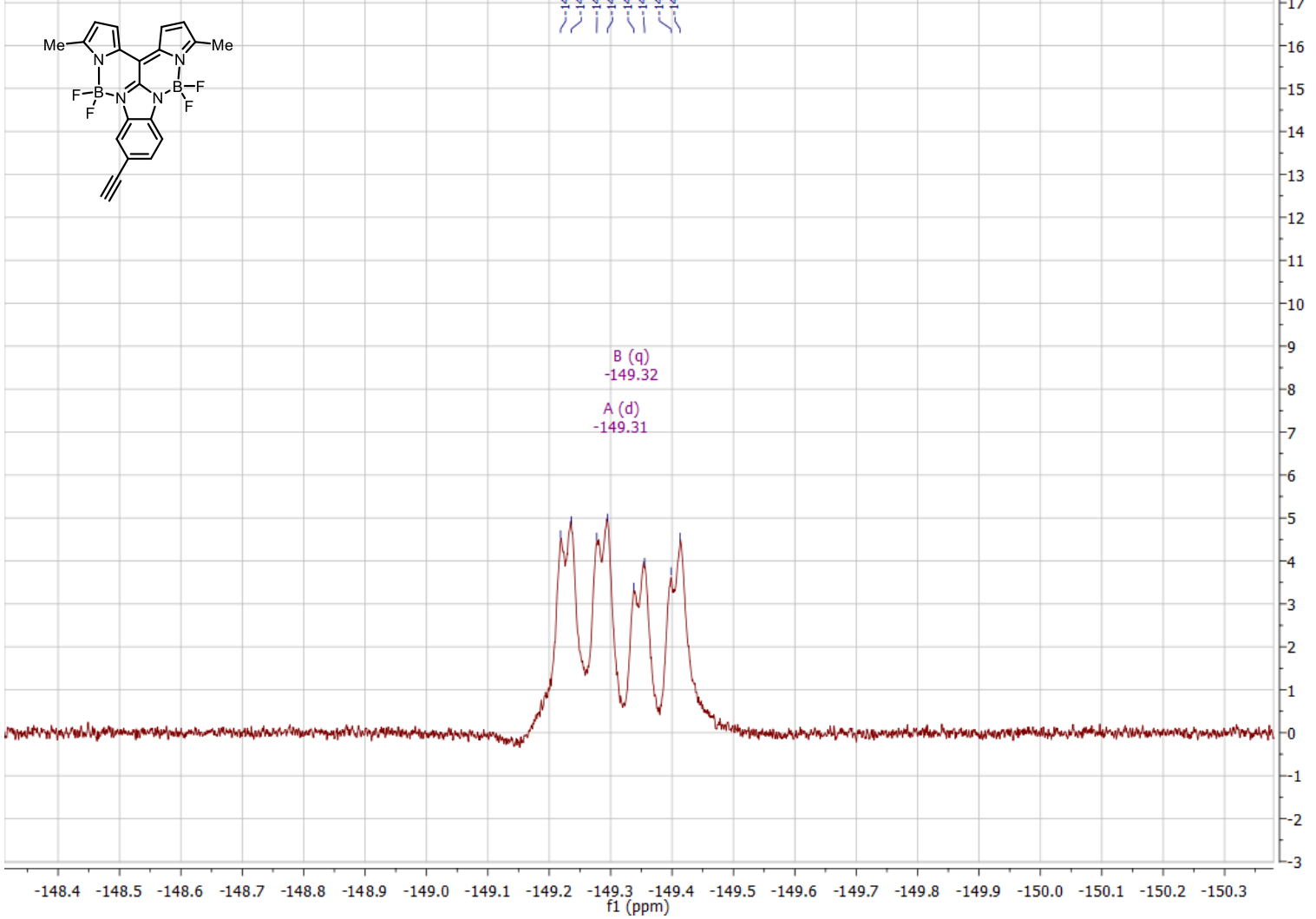

Figure S16. ${ }^{19} \mathrm{~F}$ NMR $\left(\mathrm{CDCl}_{3}, 471 \mathrm{MHz}\right)$ spectrum of $\mathbf{5 d}$. 


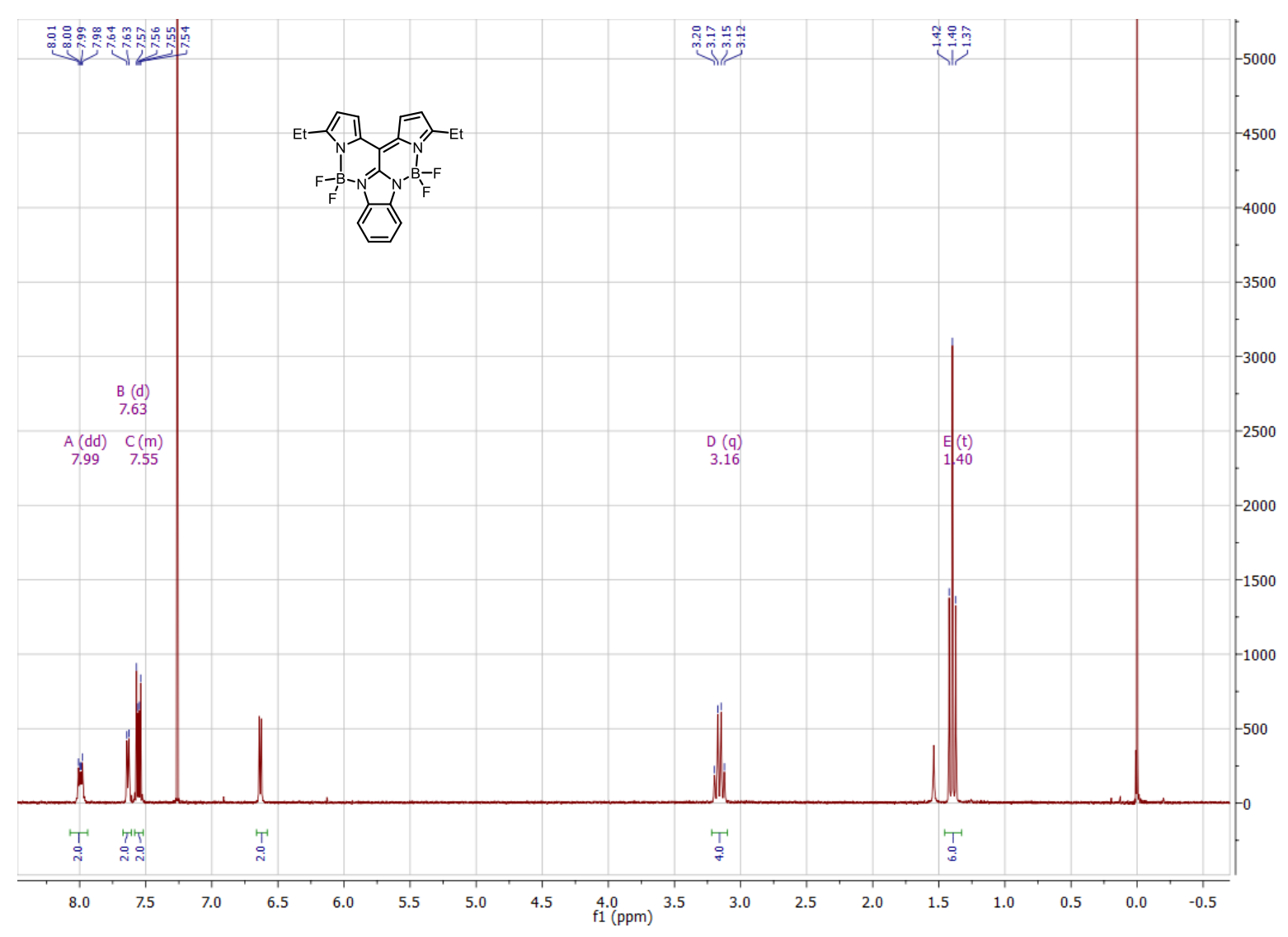

Figure S17. ${ }^{1} \mathrm{H} \mathrm{NMR}\left(\mathrm{CDCl}_{3}, 300 \mathrm{MHz}\right)$ spectrum of 5e. Analytic data is in agreement with the literature. ${ }^{[1]}$

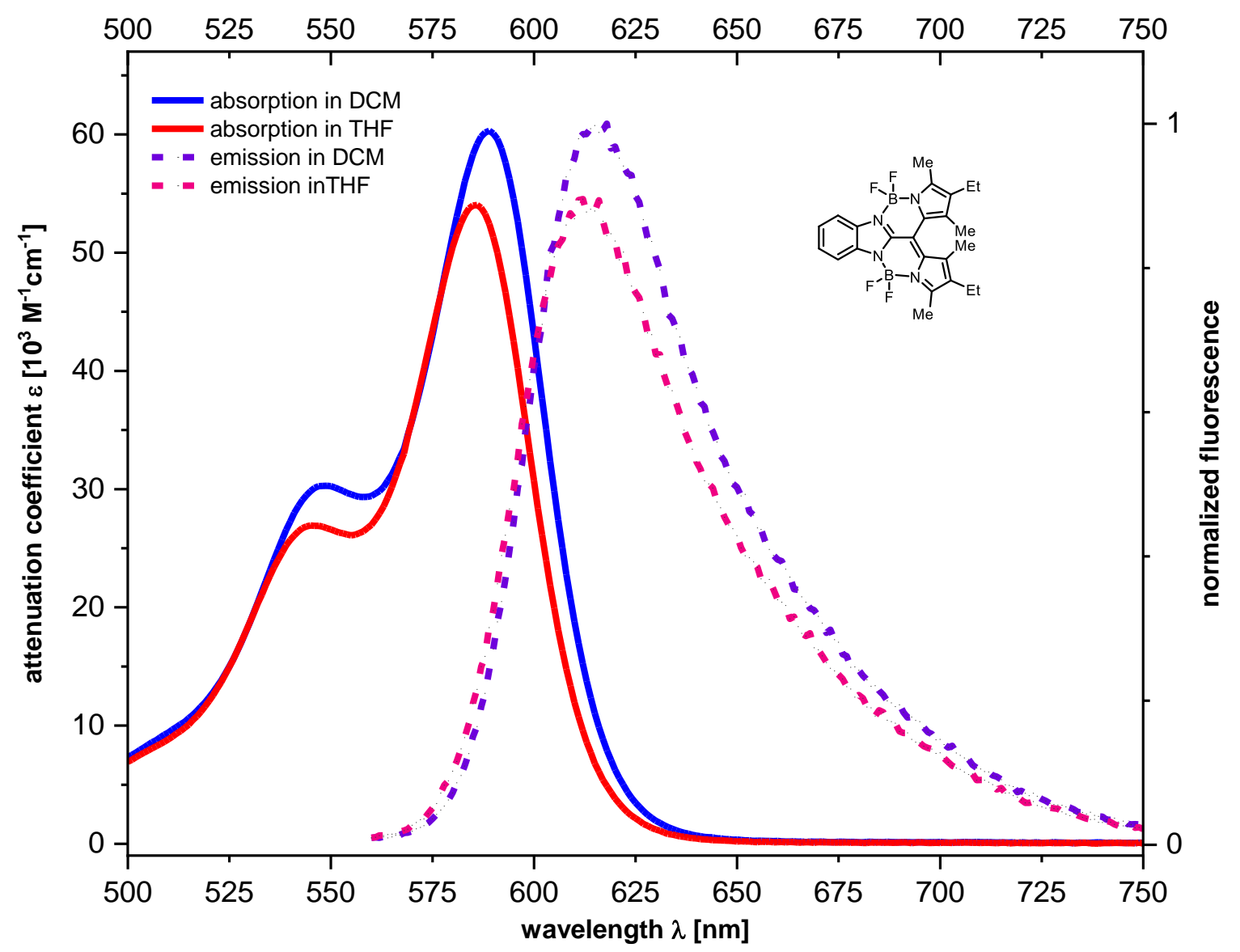

Figure S18. UV-Vis and normalized fluorescence spectra of $\mathbf{5 f}$ in DCM and THF at room temperature. 


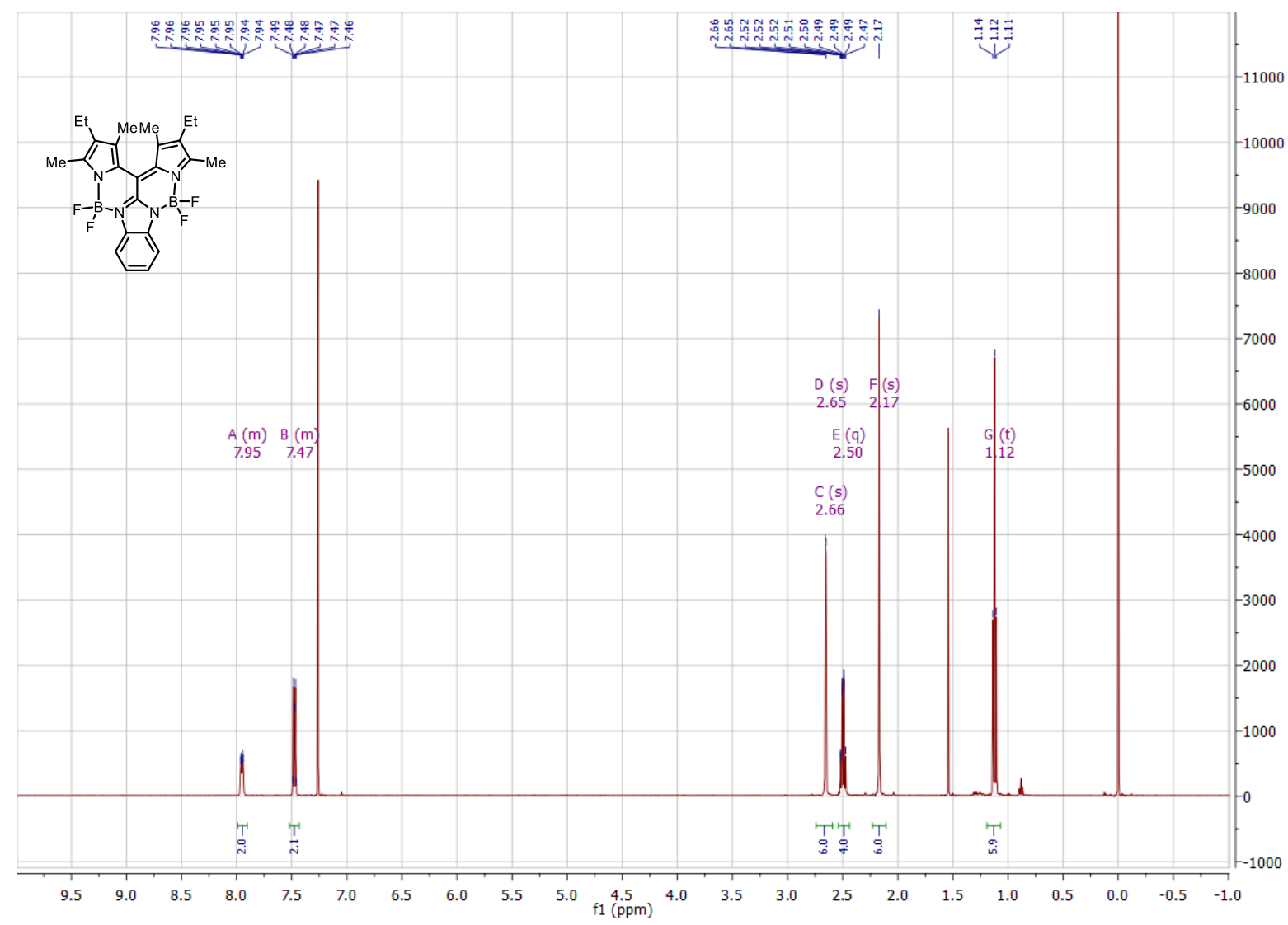

Figure S19. ${ }^{1} \mathrm{H} \mathrm{NMR}\left(\mathrm{CDCl}_{3}, 500 \mathrm{MHz}\right)$ spectrum of $\mathbf{5 f}$.

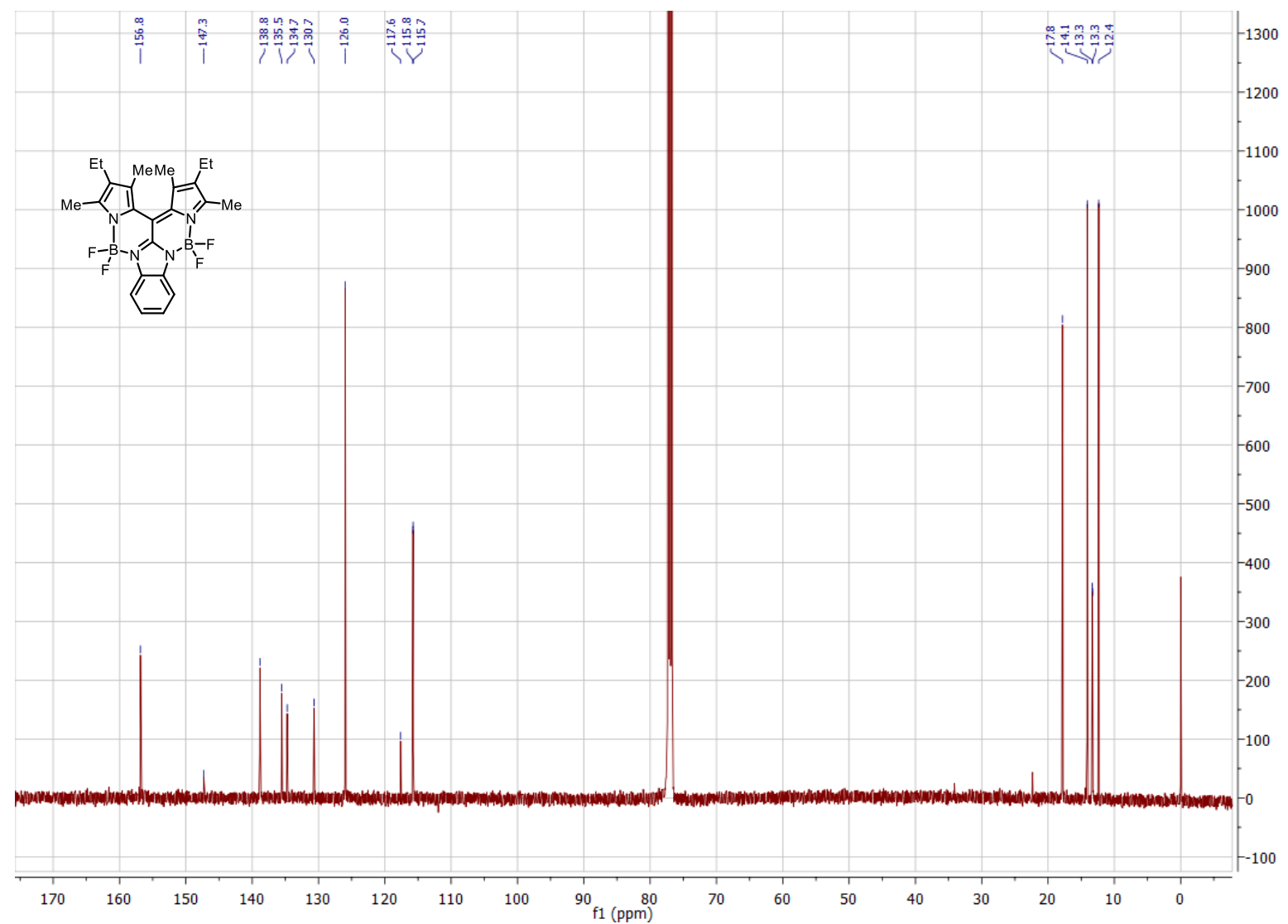

Figure S20. ${ }^{13} \mathrm{C}\left\{{ }^{1} \mathrm{H}\right\} \mathrm{NMR}\left(\mathrm{CDCl}_{3}, 125 \mathrm{MHz}\right)$ spectrum of $\mathbf{5 f}$. 


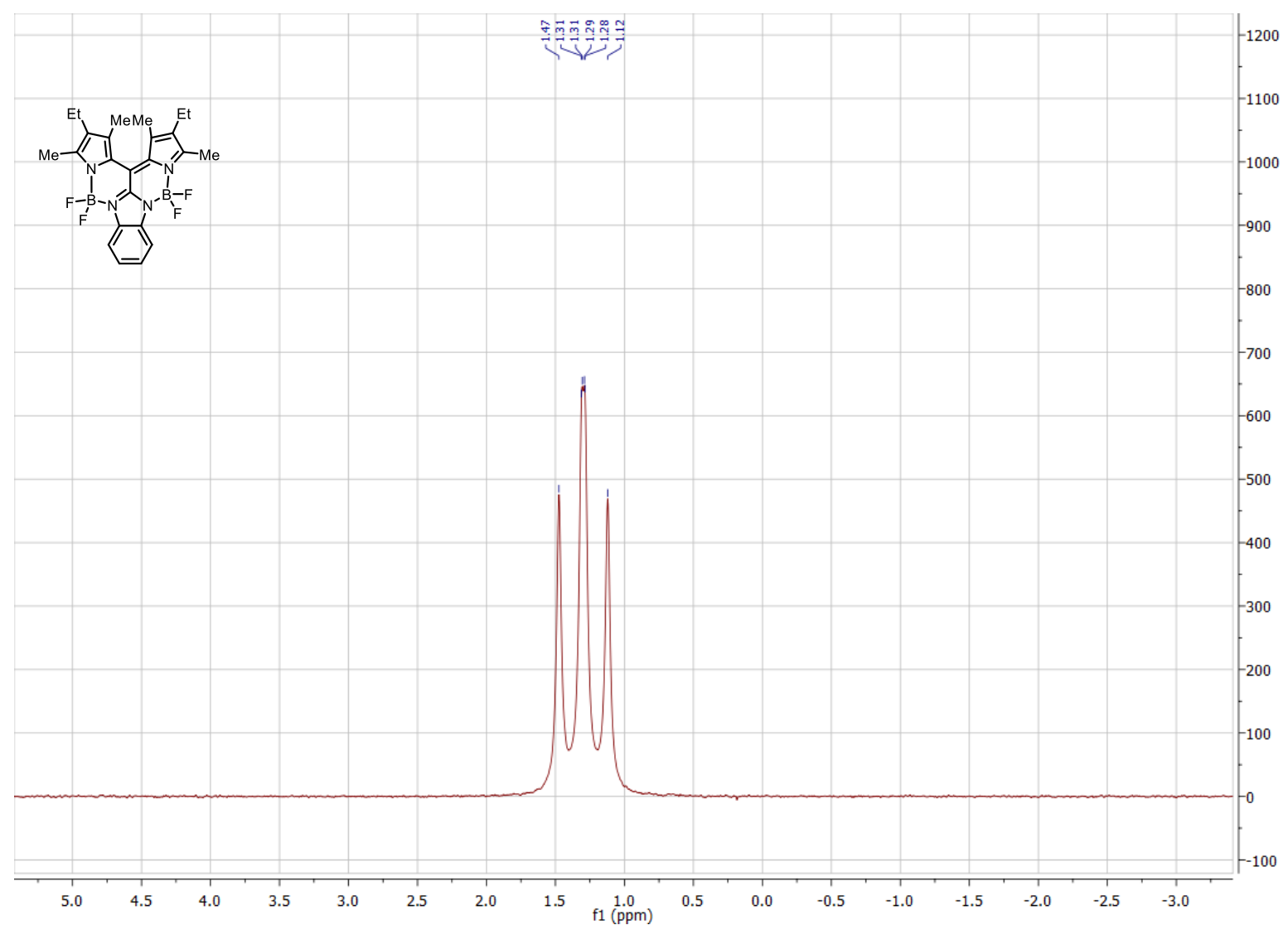

Figure S21. ${ }^{11} \mathrm{~B}$ NMR $\left(\mathrm{CDCl}_{3}, 161 \mathrm{MHz}\right)$ spectrum of $\mathbf{5 f}$.

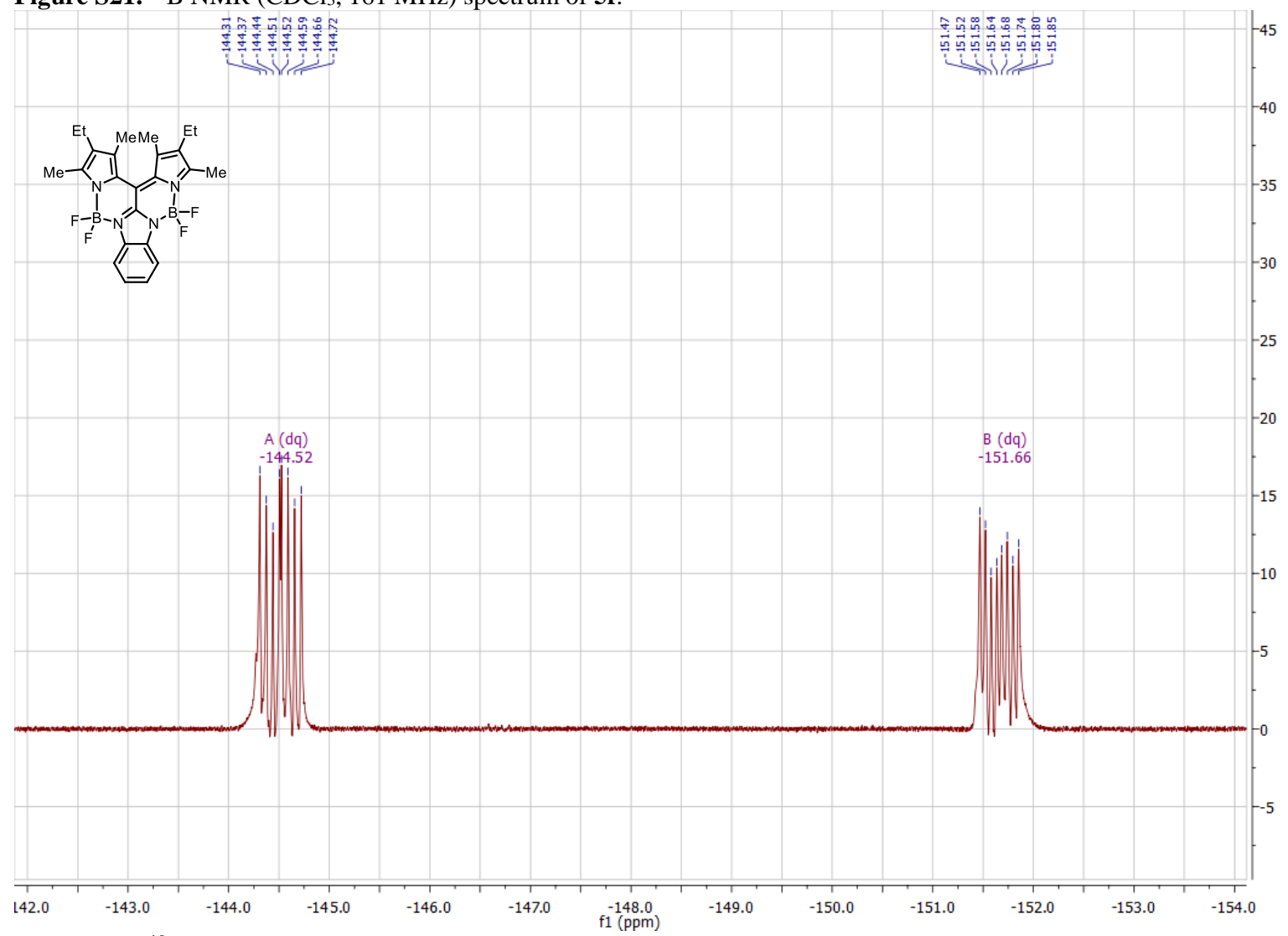

Figure S22. ${ }^{19} \mathrm{~F}$ NMR $\left(\mathrm{CDCl}_{3}, 471 \mathrm{MHz}\right)$ spectrum of $\mathbf{5 f}$. 


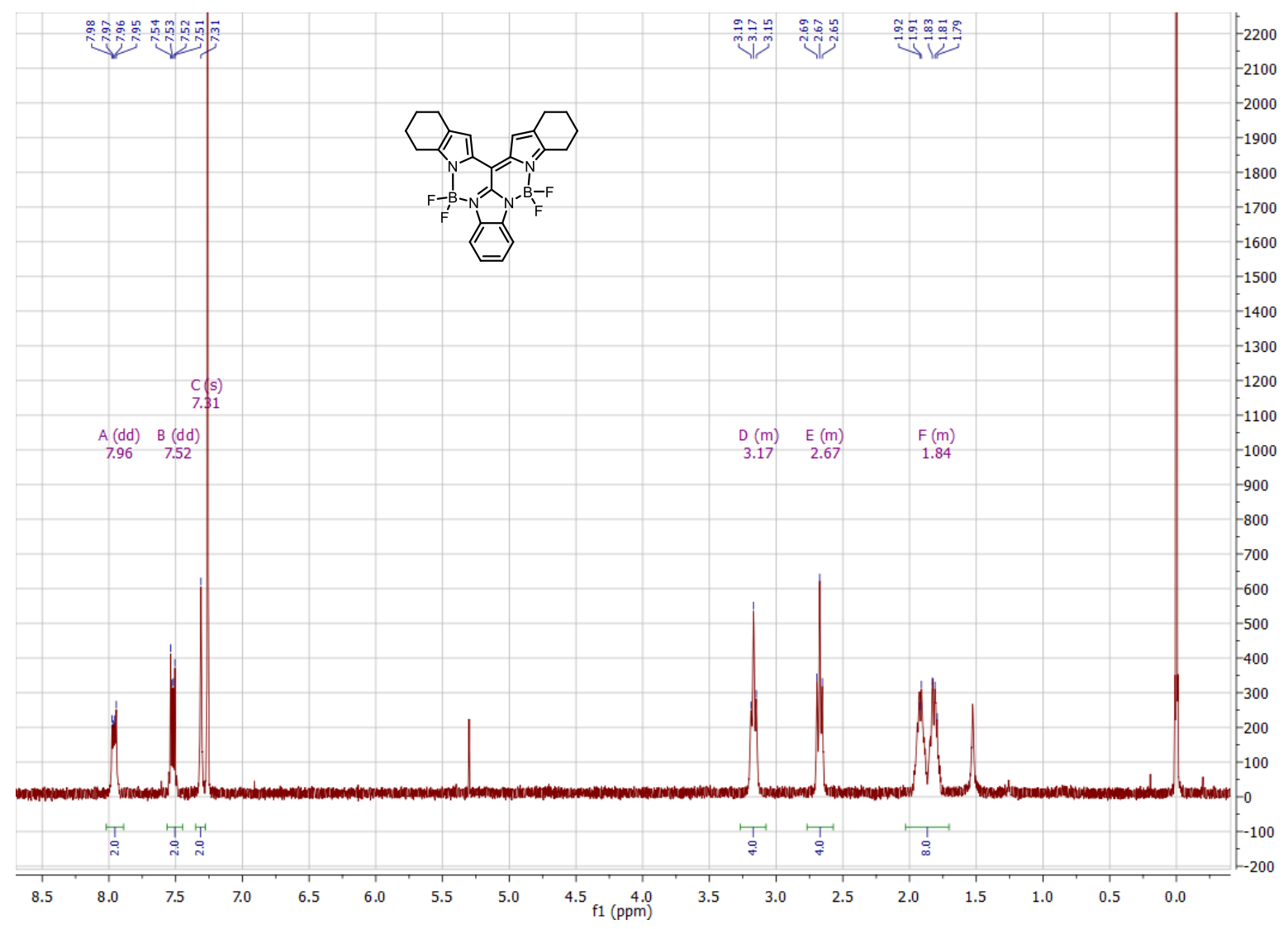

Figure S23. ${ }^{1} \mathrm{H}$ NMR $\left(\mathrm{CDCl}_{3}, 300 \mathrm{MHz}\right)$ spectrum of $\mathbf{5 g}$. Analytic data is in agreement with the literature. ${ }^{[1]}$

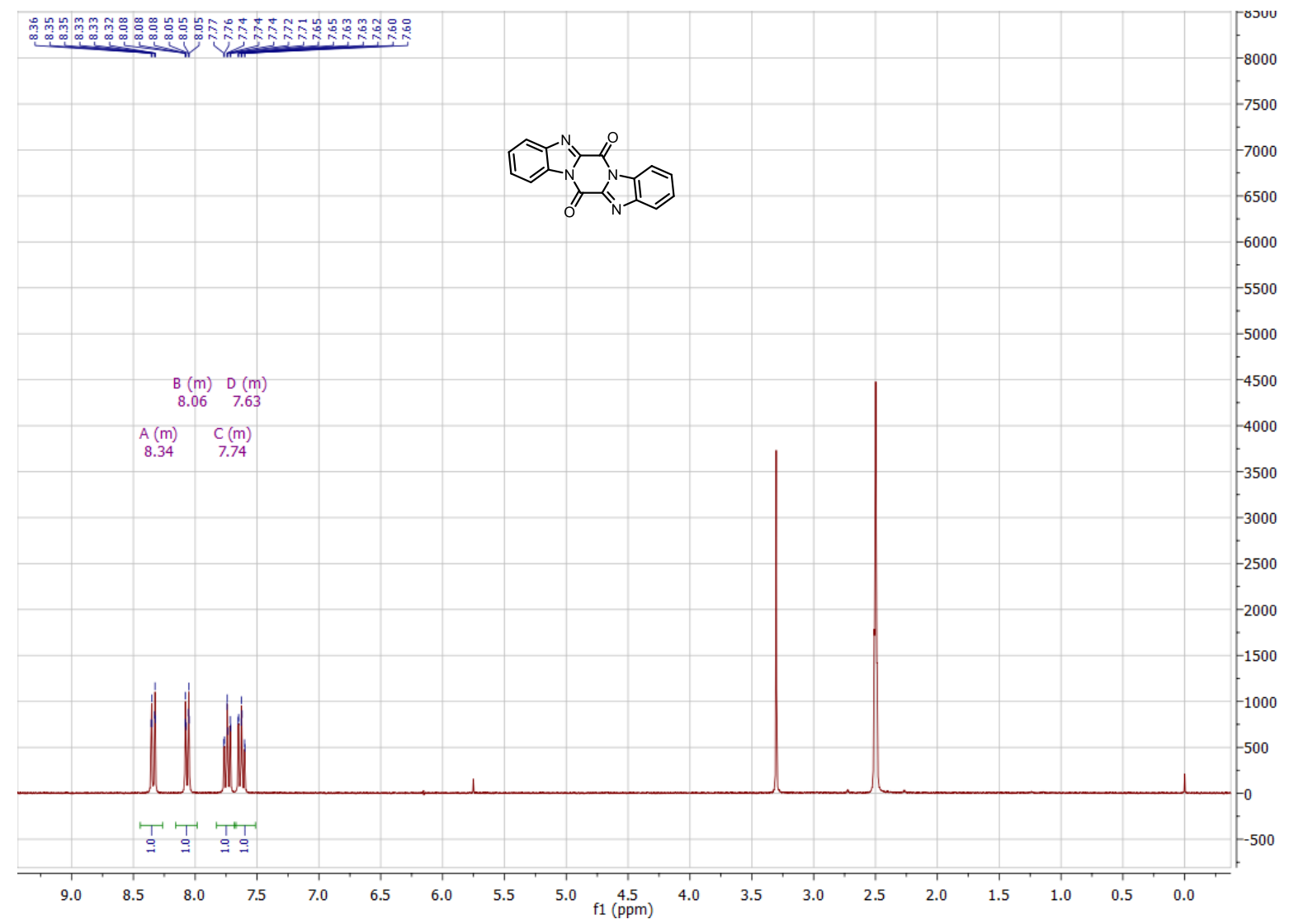

Figure 24. ${ }^{1} \mathrm{H}$ NMR (DMSO- $d_{6}, 300 \mathrm{MHz}$ ) spectrum of 6a. Analytic data is in agreement with the literature. ${ }^{[2]}$ 


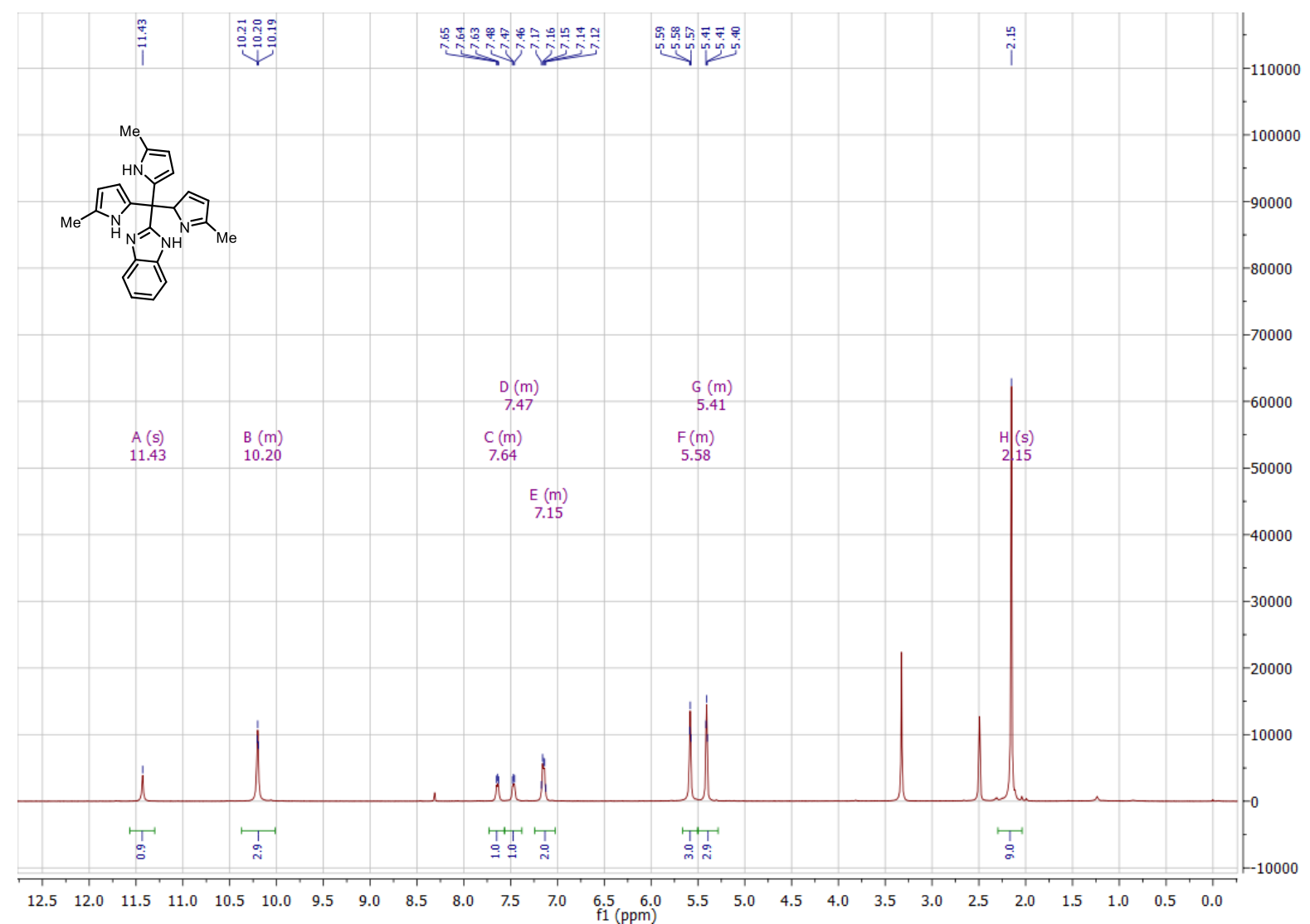

Figure S25. ${ }^{1} \mathrm{H}$ NMR (DMSO- $d_{6}, 400 \mathrm{MHz}$ ) spectrum of $\mathbf{7 a}$.

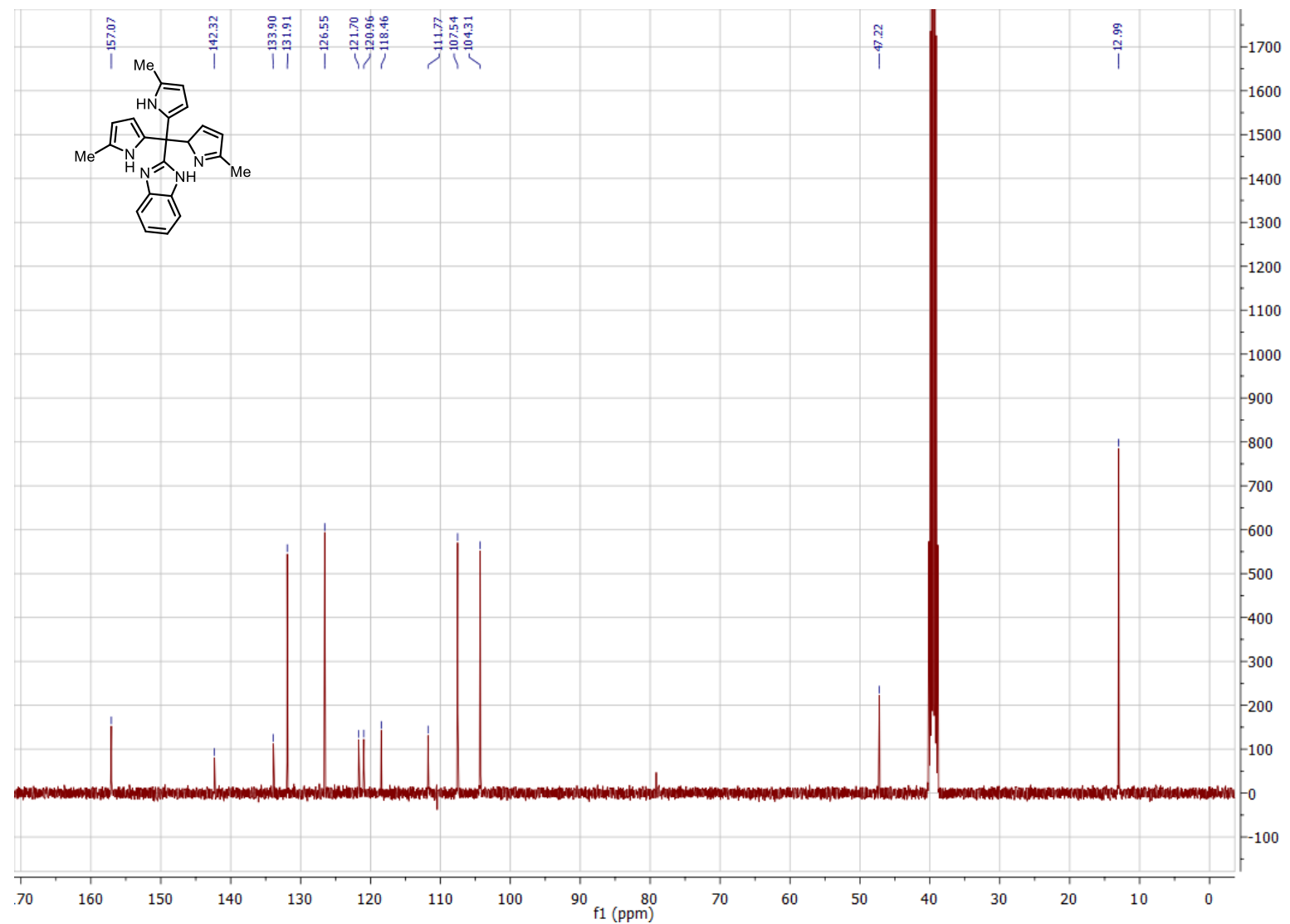

Figure S26. ${ }^{13} \mathrm{C}\left\{{ }^{1} \mathrm{H}\right\}$ NMR (DMSO- $d_{6}, 100 \mathrm{MHz}$ ) spectrum of $7 \mathbf{a}$. 


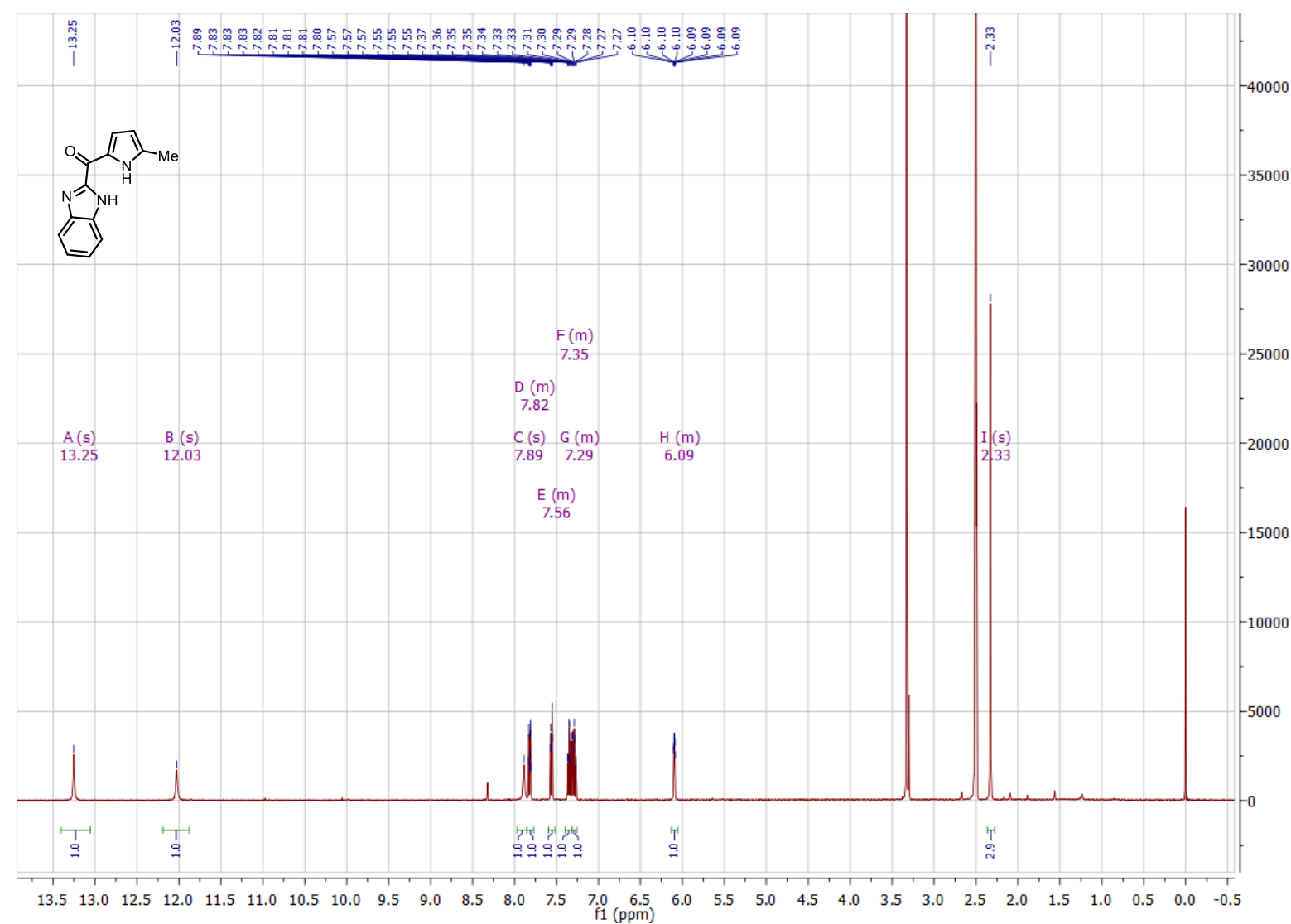

Figure S27. ${ }^{1} \mathrm{H}$ NMR (DMSO- $d_{6}, 400 \mathrm{MHz}$ ) spectrum of $\mathbf{3 a}$.

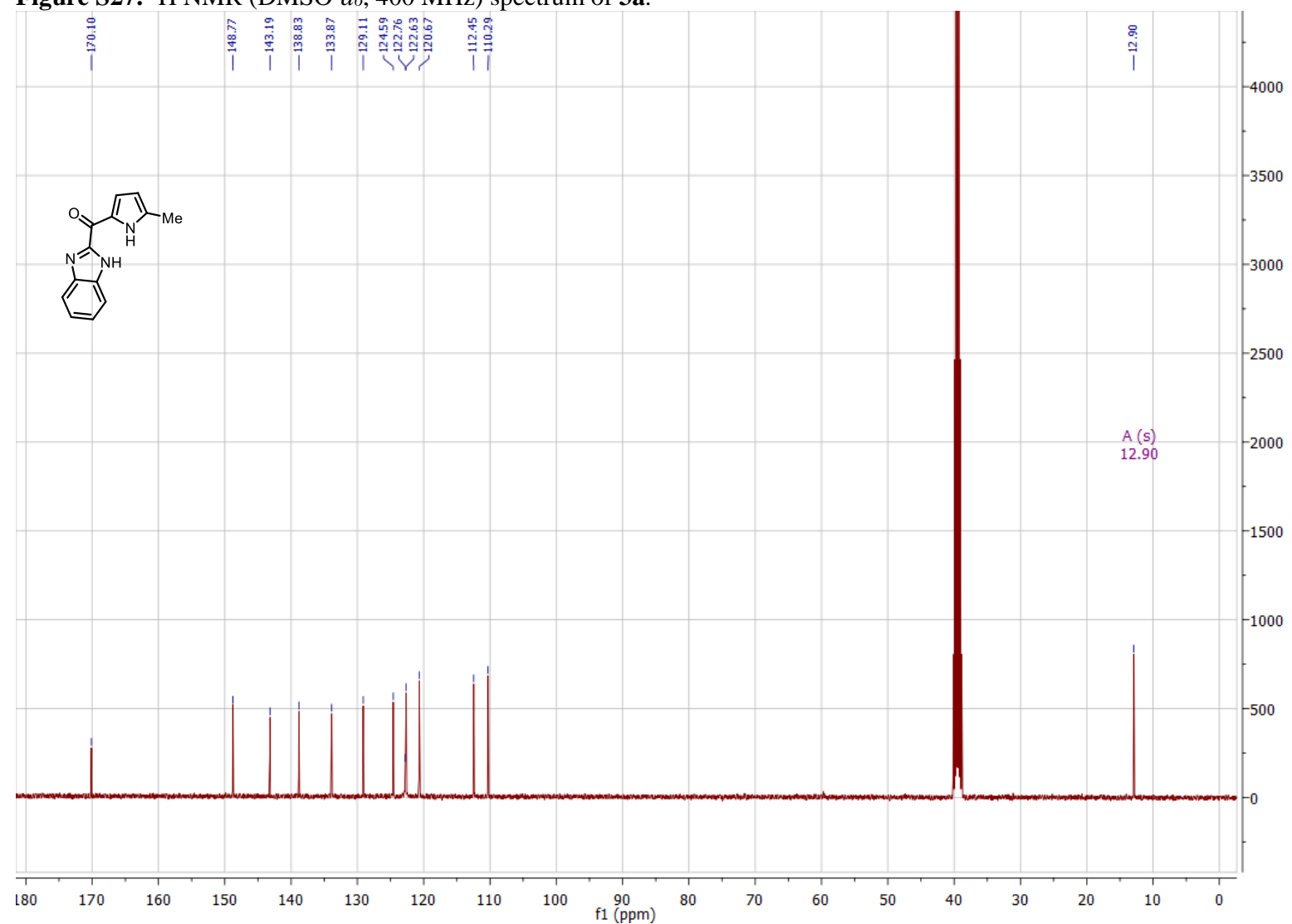

Figure S28. ${ }^{13} \mathrm{C}$ NMR (DMSO- $d_{6}, 100 \mathrm{MHz}$ ) spectrum of 3a. 


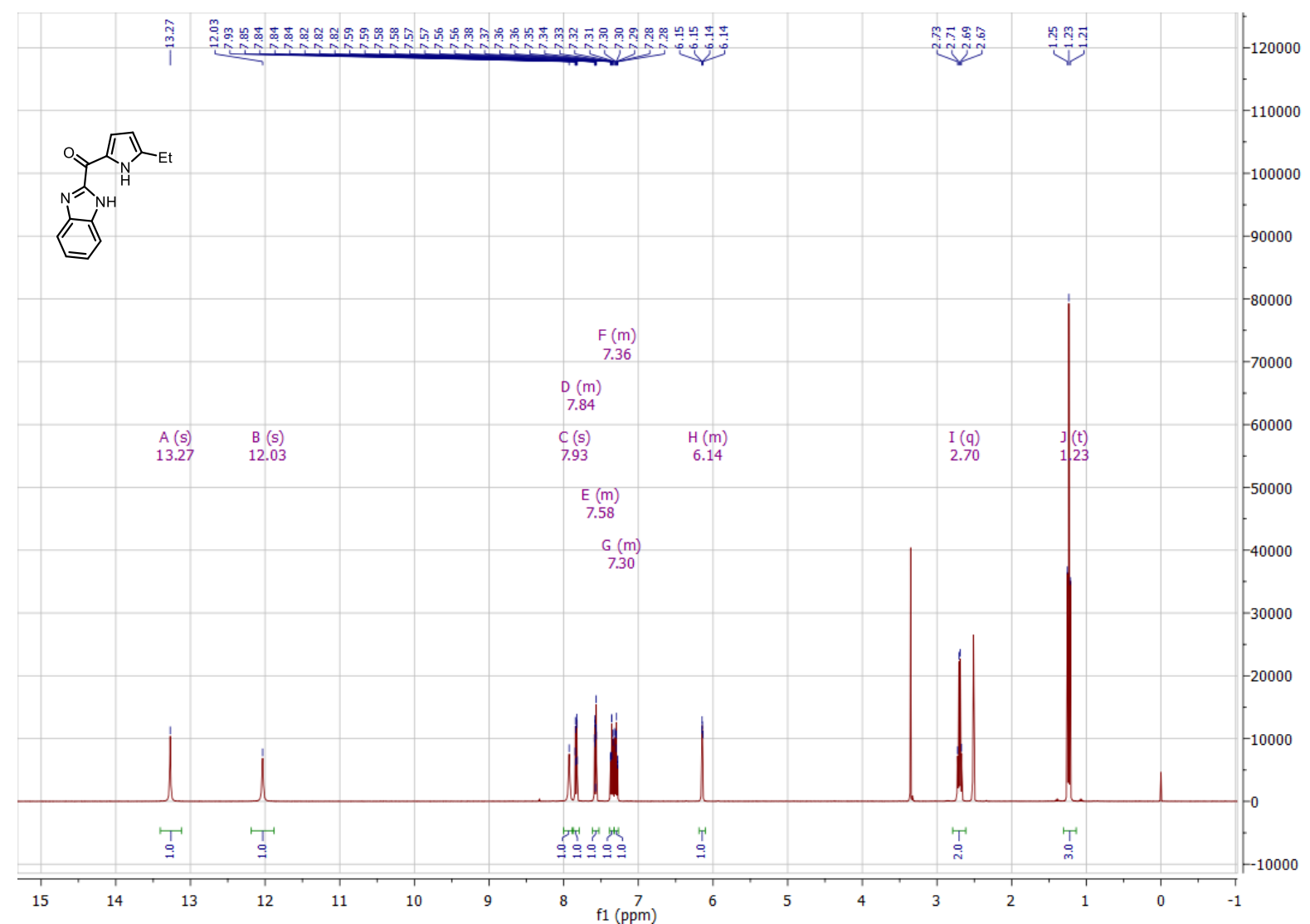

Figure S29. ${ }^{1} \mathrm{H}$ NMR (DMSO- $d 6,400 \mathrm{MHz}$ ) spectrum of $\mathbf{3 b}$.

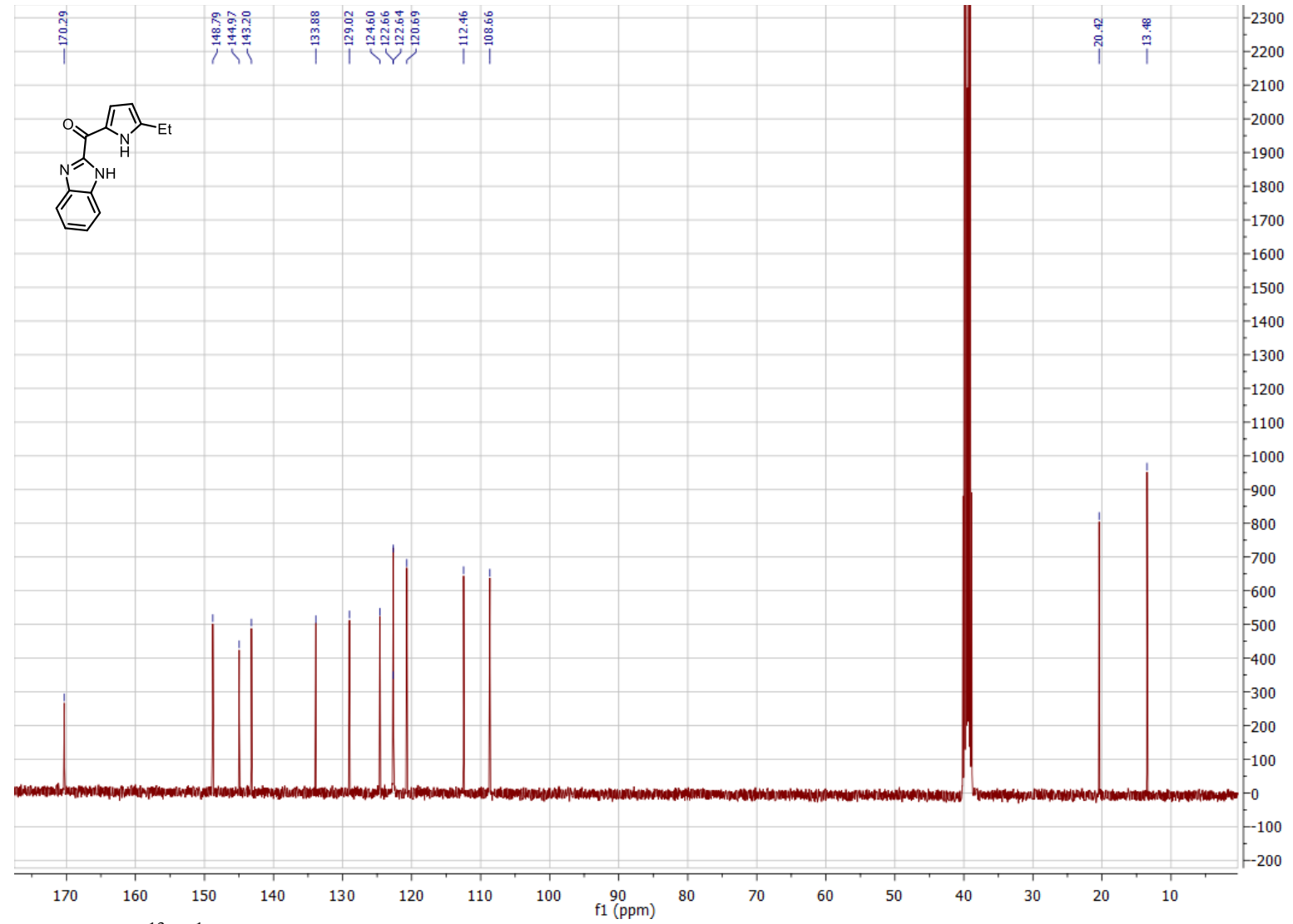

Figure S30. ${ }^{13} \mathrm{C}\left\{{ }^{1} \mathrm{H}\right\}$ NMR (DMSO- $d 6,100 \mathrm{MHz}$ ) spectrum of $\mathbf{3 b}$. 


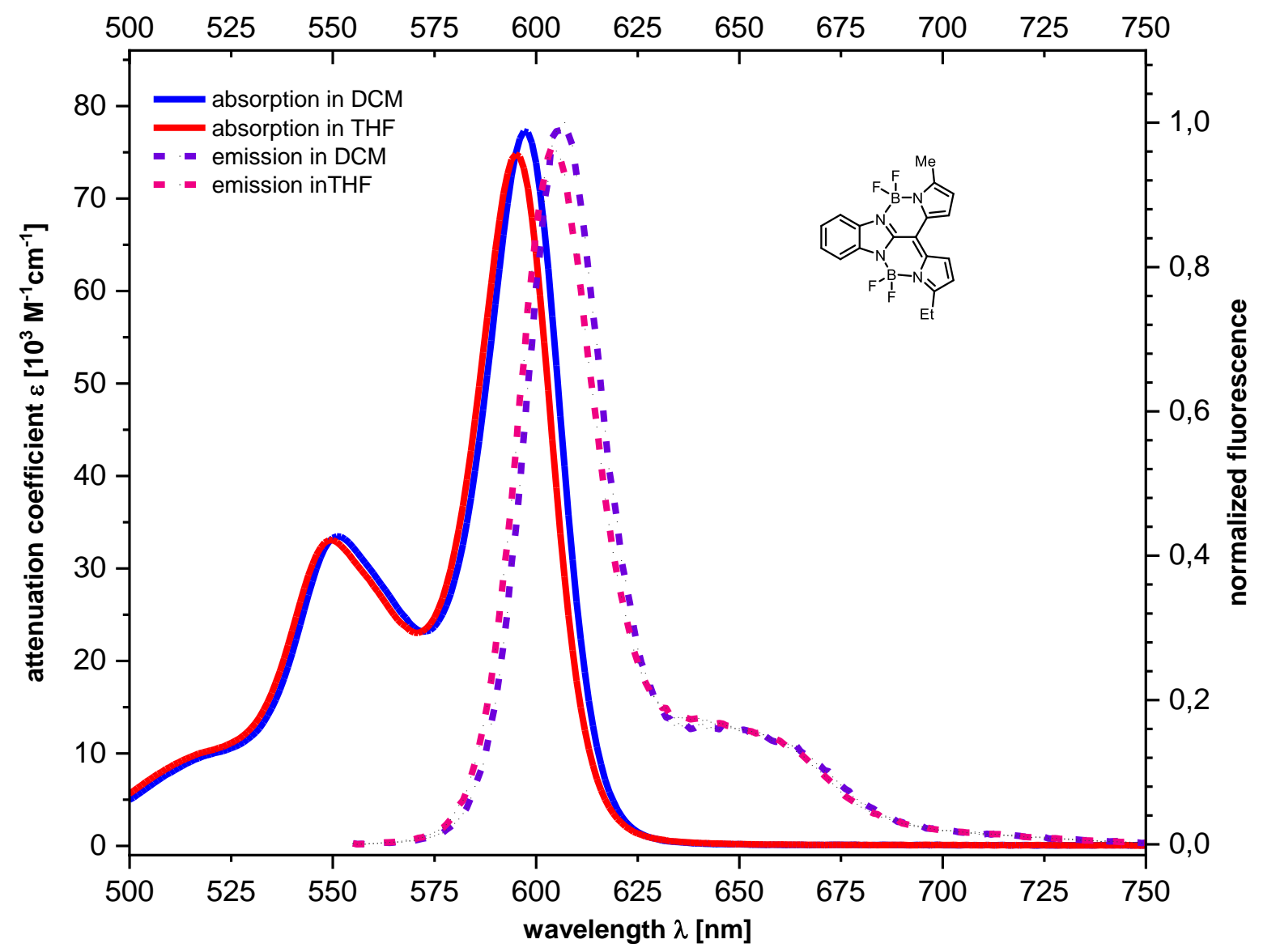

Figure S31. UV-Vis and normalized fluorescence spectra of 8a in DCM and THF at room temperature.

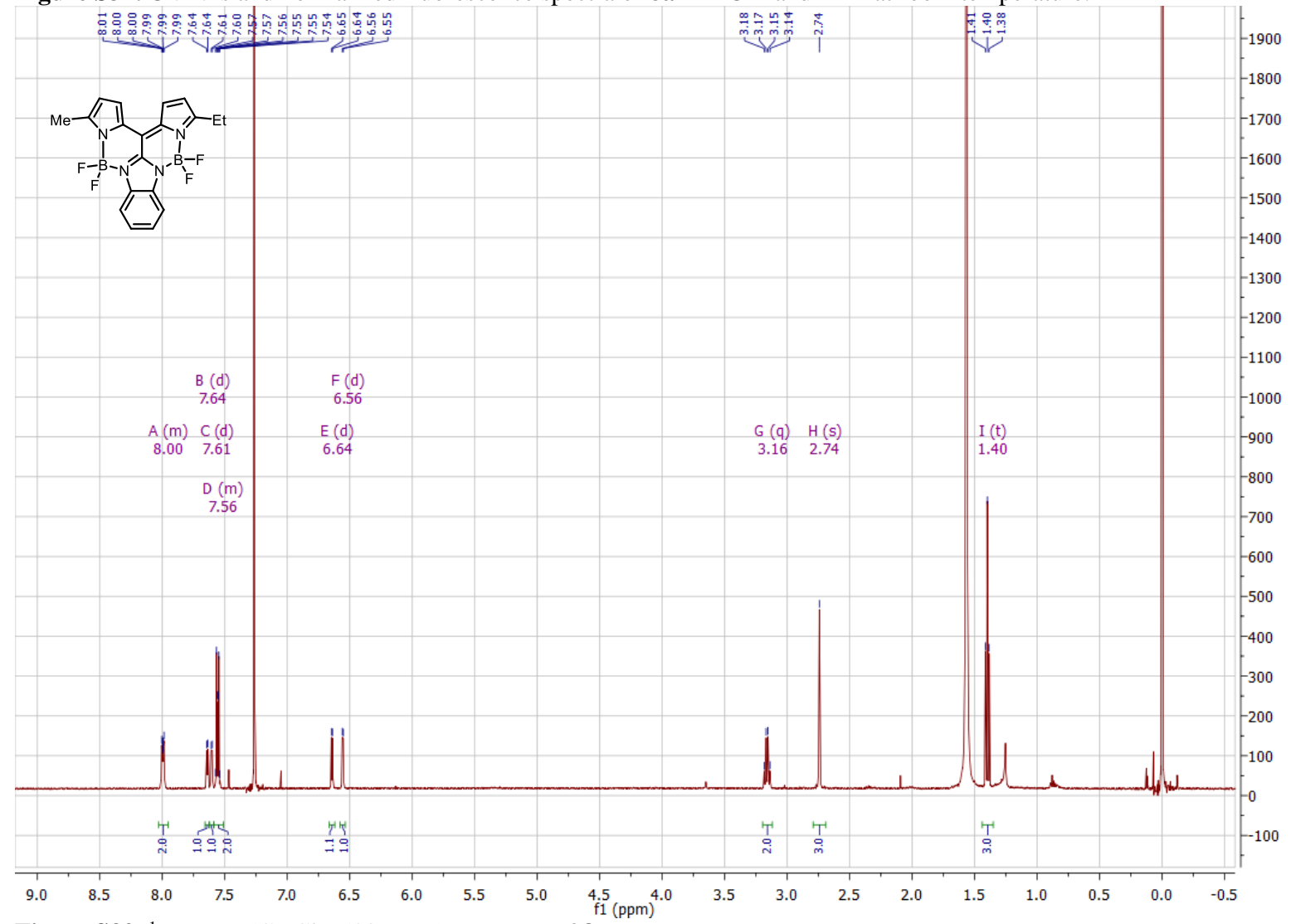

Figure S32. ${ }^{1} \mathrm{H}$ NMR $\left(\mathrm{CDCl}_{3}, 500 \mathrm{MHz}\right)$ spectrum of $\mathbf{8 a}$. 


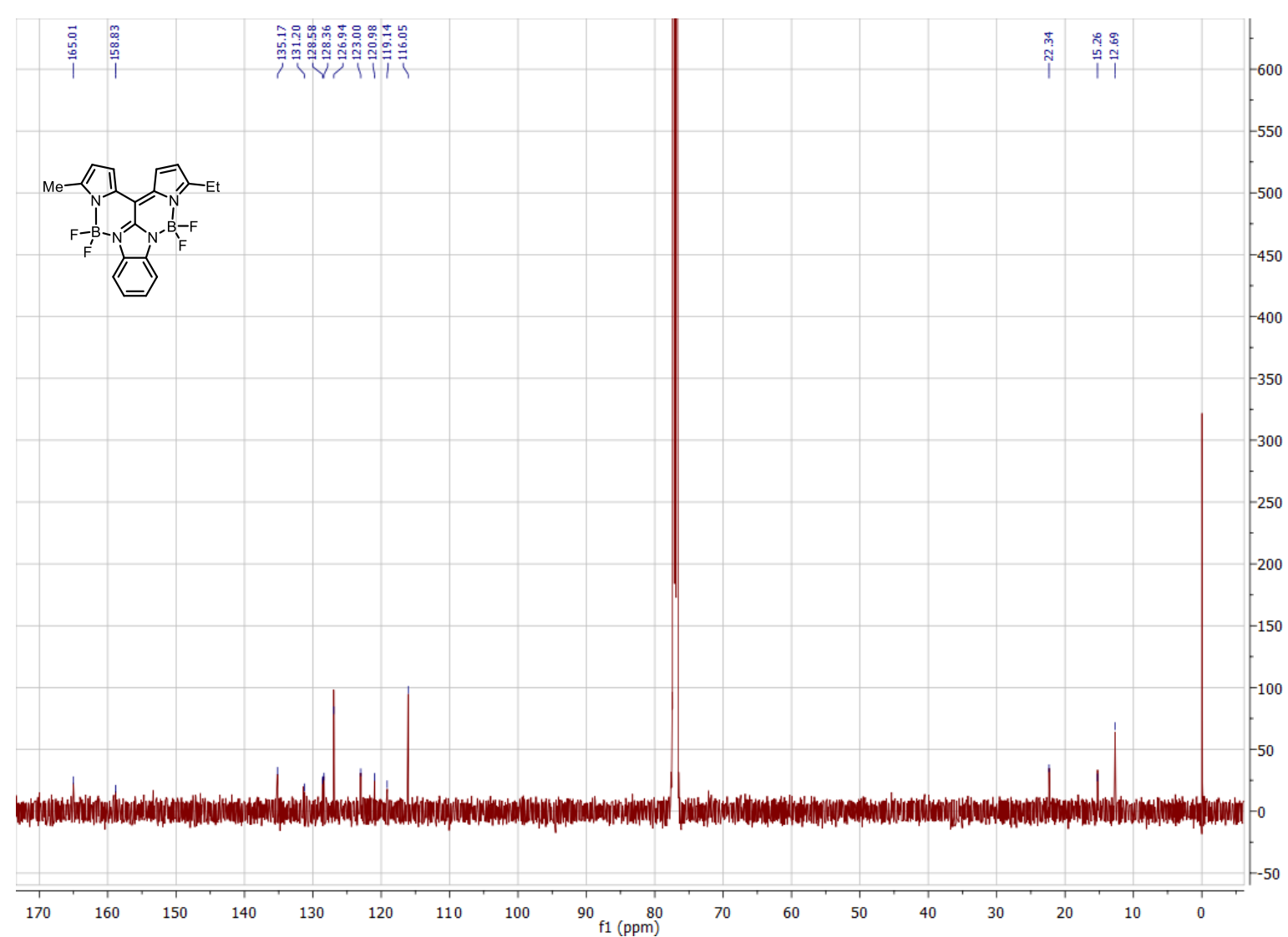

Figure S33. ${ }^{13} \mathrm{C}\left\{{ }^{1} \mathrm{H}\right\} \mathrm{NMR}\left(\mathrm{CDCl}_{3}, 125 \mathrm{MHz}\right)$ spectrum of $\mathbf{8 a}$.

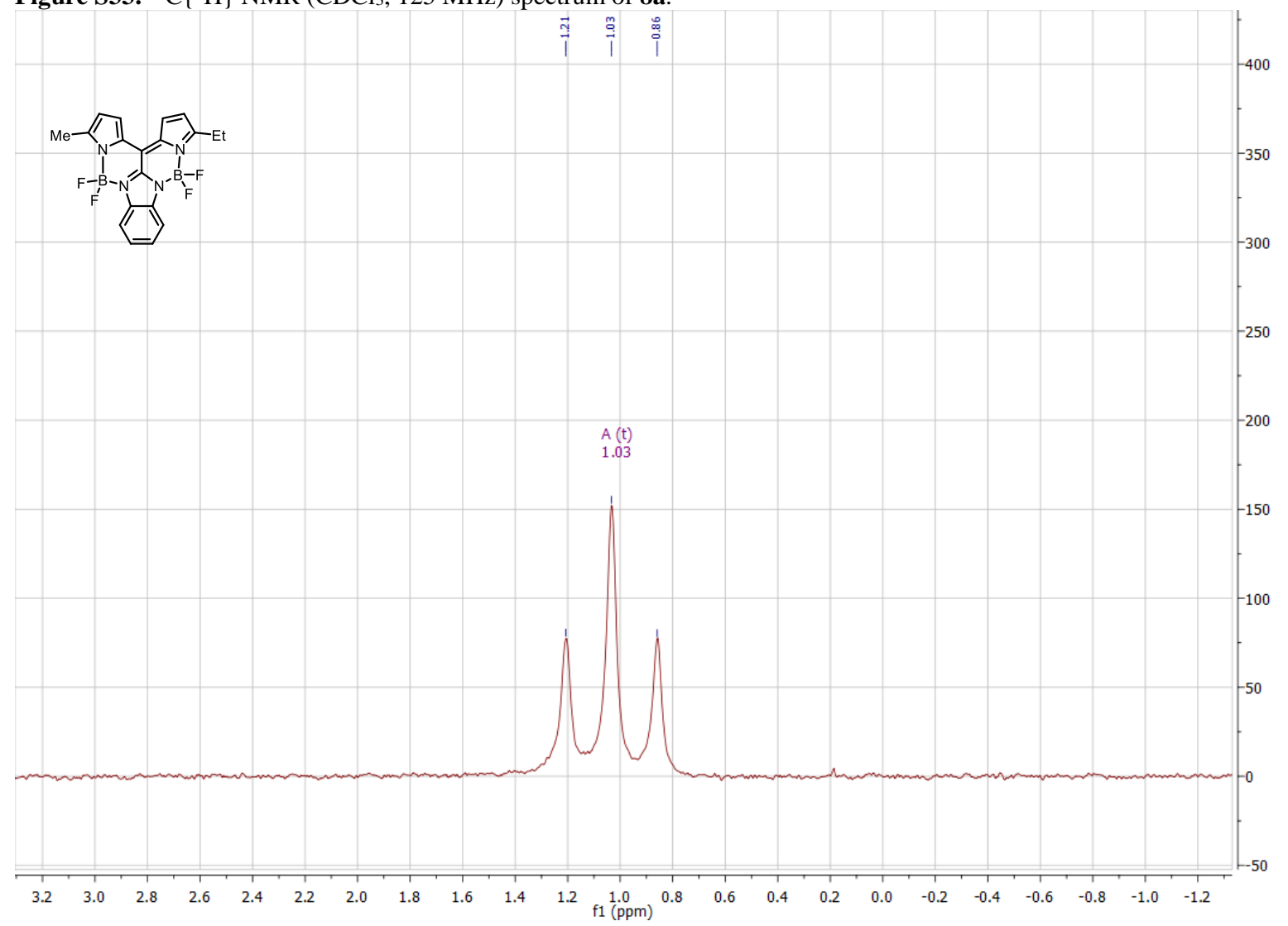

Figure S34. ${ }^{11} \mathrm{~B} \mathrm{NMR}\left(\mathrm{CDCl}_{3}, 161 \mathrm{MHz}\right)$ spectrum of $\mathbf{8 a}$. 


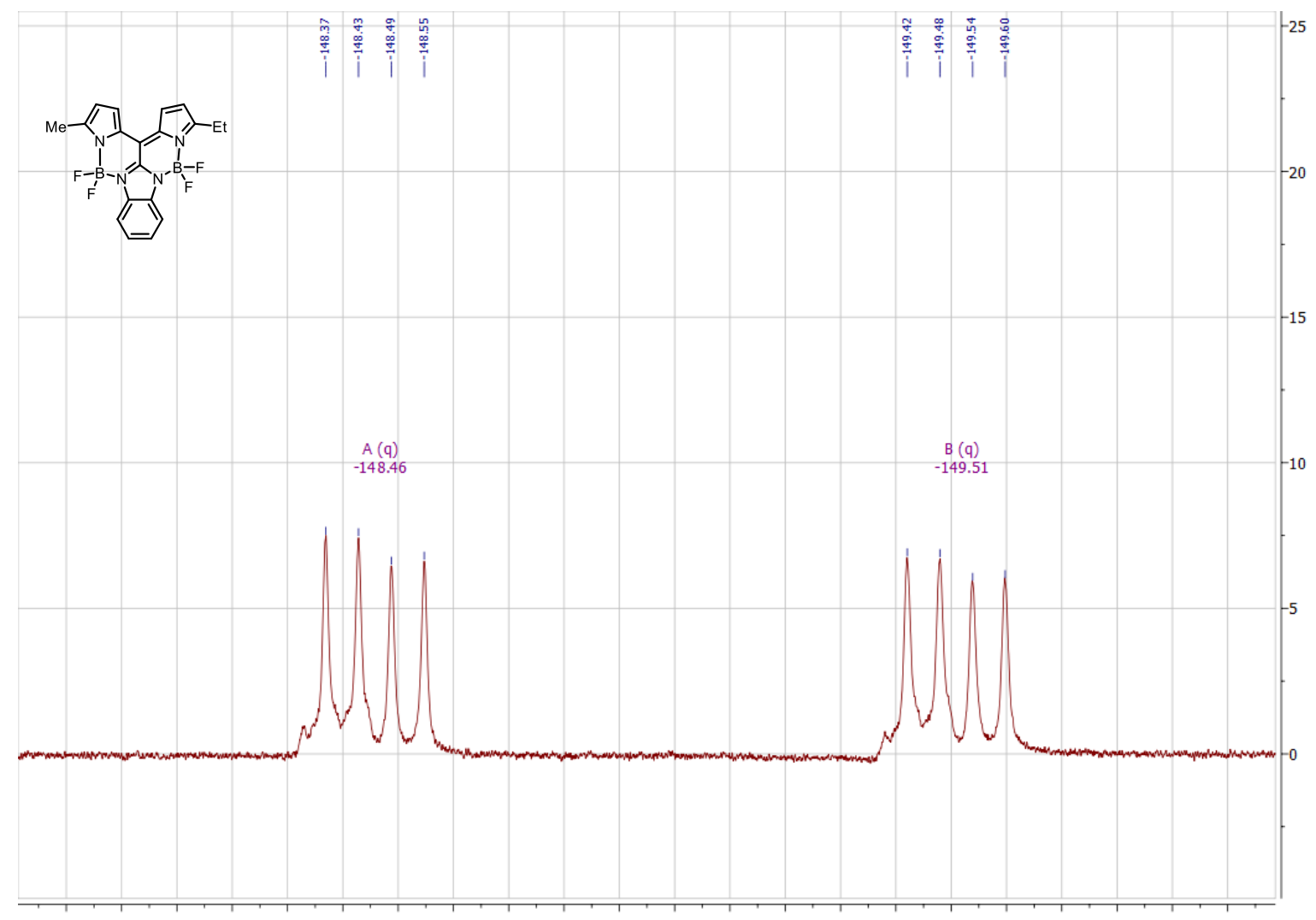

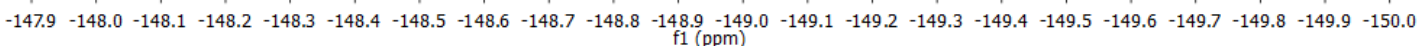
Figure S35. ${ }^{19} \mathrm{~F}$ NMR $\left(\mathrm{CDCl}_{3}, 471 \mathrm{MHz}\right)$ spectrum of $\mathbf{8 a}$.

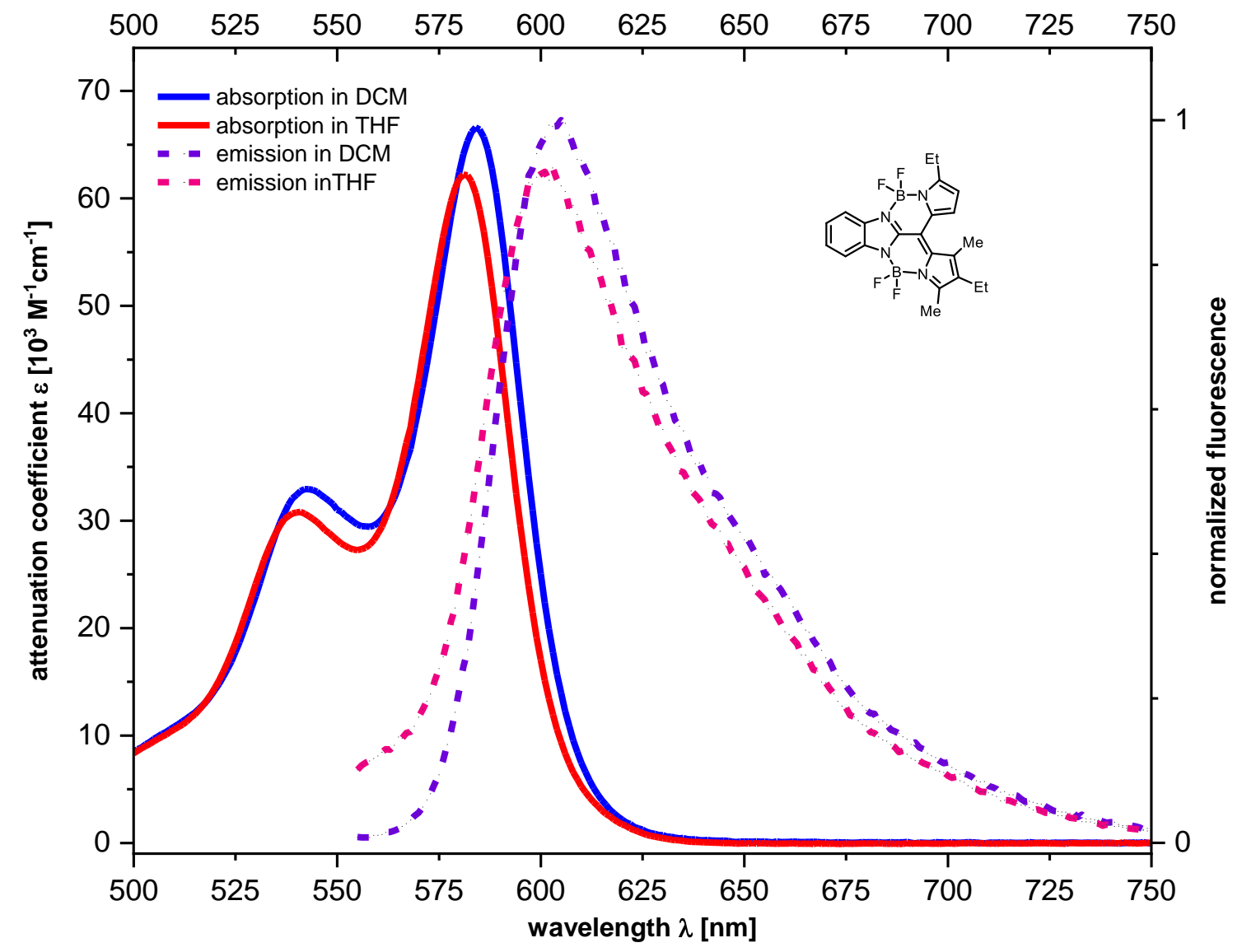

Figure S36. UV-Vis and normalized fluorescence spectra of $\mathbf{8 b}$ in DCM and THF at room temperature. 


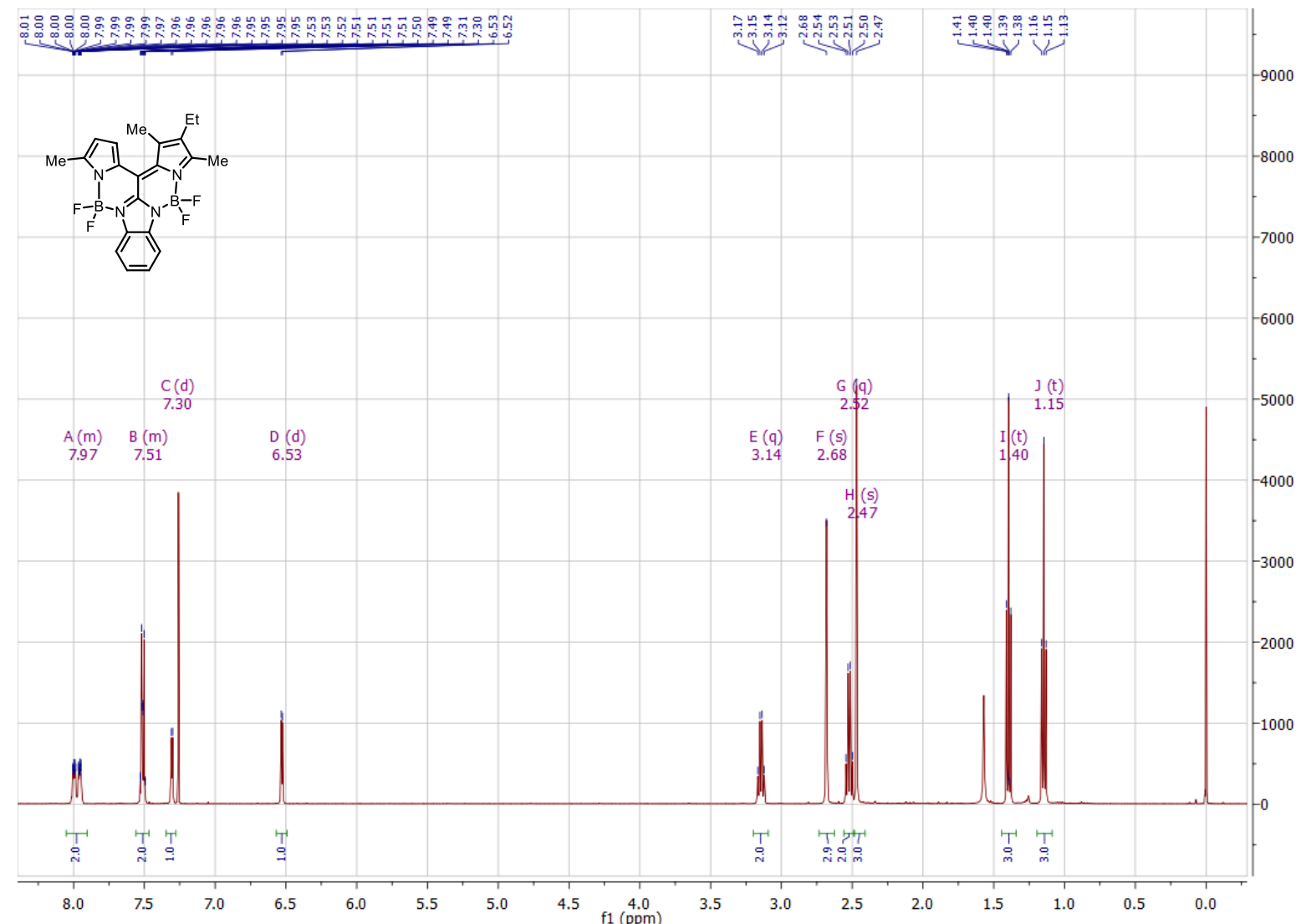

Figure S37. ${ }^{1} \mathrm{H}$ NMR $\left(\mathrm{CDCl}_{3}, 500 \mathrm{MHz}\right)$ spectrum of $\mathbf{8 b}$.

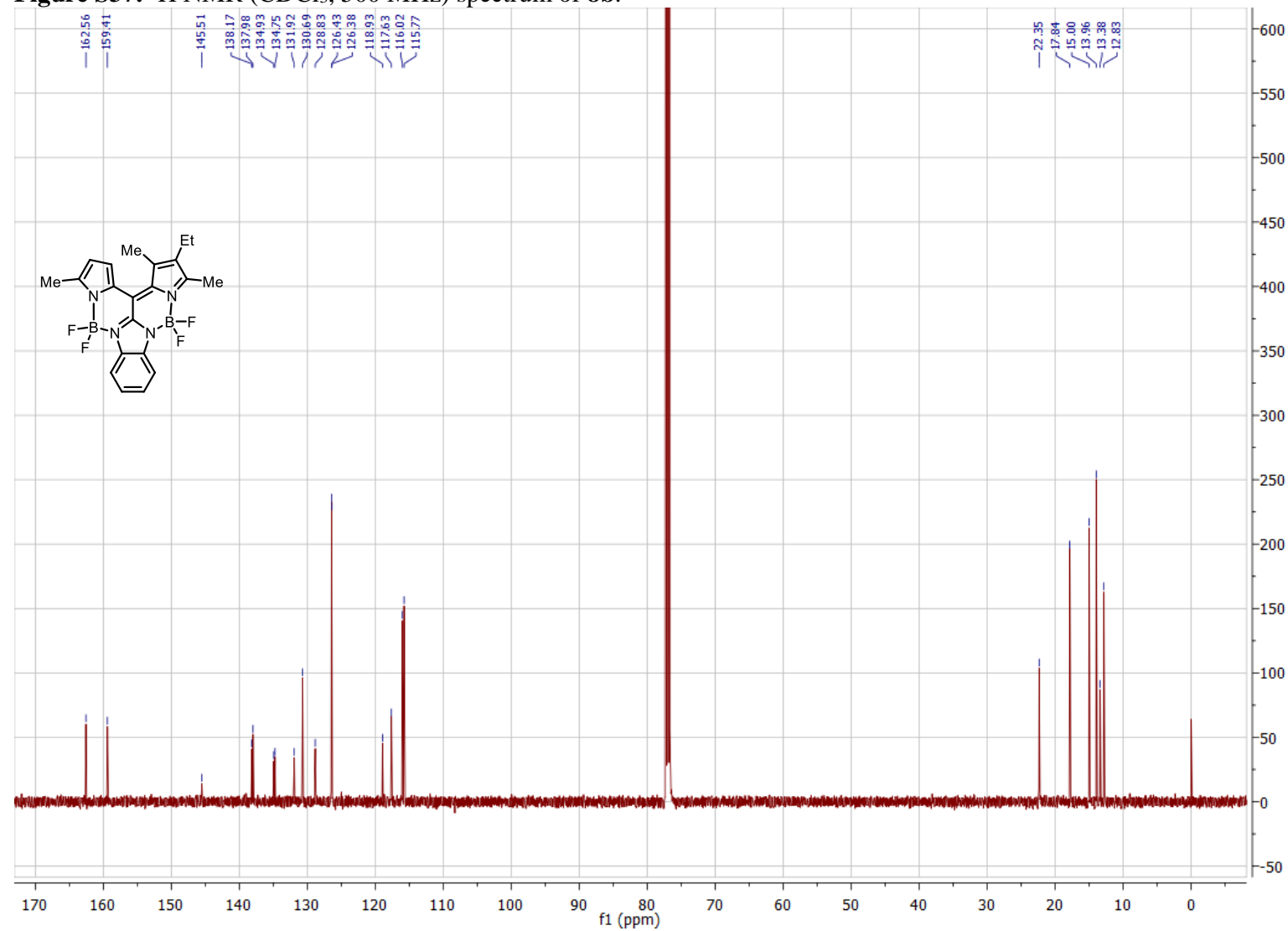

Figure S38. ${ }^{13} \mathrm{C}\left\{{ }^{1} \mathrm{H}\right\} \mathrm{NMR}\left(\mathrm{CDCl}_{3}, 125 \mathrm{MHz}\right)$ spectrum of $\mathbf{8 b}$. 


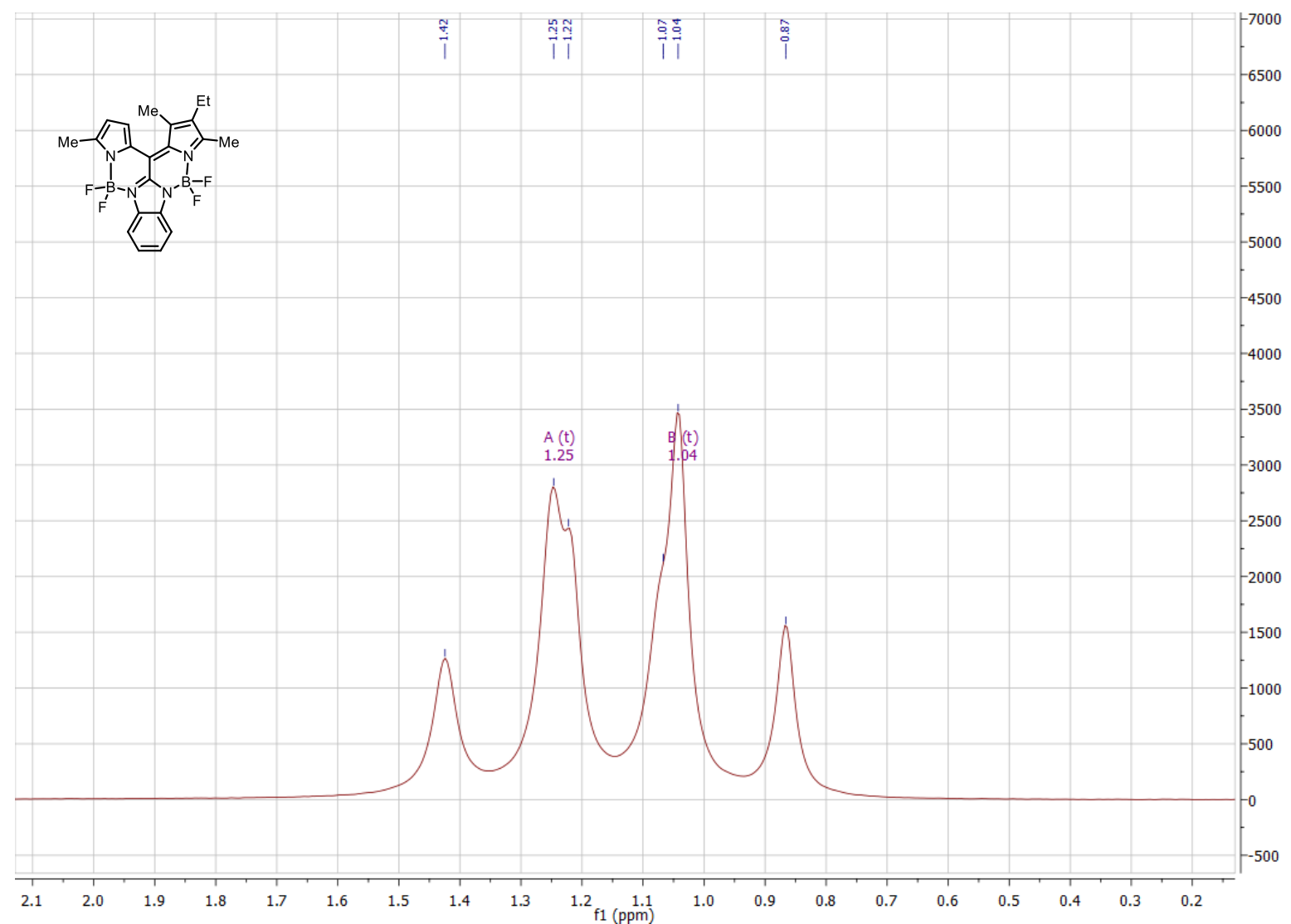

Figure S39. ${ }^{11} \mathrm{~B} \mathrm{NMR}\left(\mathrm{CDCl}_{3}, 161 \mathrm{MHz}\right)$ spectrum of $\mathbf{8 b}$.

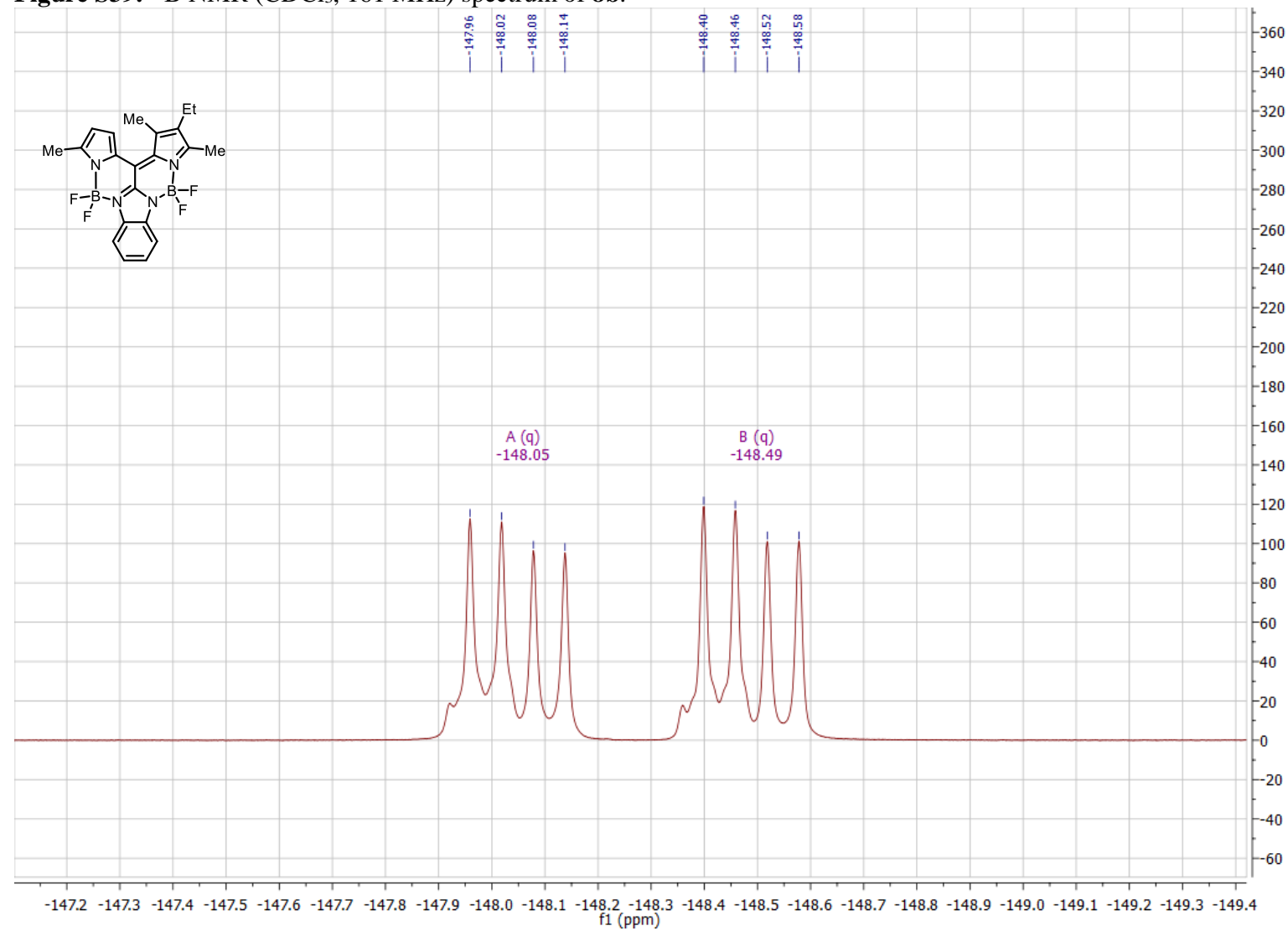

Figure S40. ${ }^{19} \mathrm{~F}$ NMR $\left(\mathrm{CDCl}_{3}, 471 \mathrm{MHz}\right)$ spectrum of $\mathbf{8 b}$. 


\section{X-Ray Crystallographic Results}

\section{Crystal Structure Determinations}

Both compounds were recrystallized by evaporation of a solution in a mixture of chloroform and $n$-hexane at room temperature. Crystals were mounted in inert oil on nylon loops and transferred to the cold gas stream of a Rigaku/Oxford XtaLAB Synergy diffractometer. Intensity data were recorded using mirror-focussed Mo-K $\alpha$ radiation. Absorption corrections were implemented on the basis of multi-scans. The structures were refined anisotropically on $F^{2}$ using the program SHELXL-2018. ${ }^{[3]}$ Hydrogen atoms were included using rigid methyl groups or a riding model starting from calculated positions.

Special features: The symmetry of compound $\mathbf{8 a}$ is approximately that of space group $P(-1)$, but this would involve disorder of the ethyl and methyl groups (by superposition); in $P 1$, an unusual space group for compounds that are not pure enantiomers, the structure is ordered. The largest difference peak may correspond to a small extent of such a disorder. The structure was refined as a two-component inversion twin. The anomalous dispersion effects were however at best weak and the Flack parameter is almost indeterminate.

Crystallographic data are summarized in Table S2. Additionally, complete data have been deposited with the Cambridge Crystallographic Data Centre under the numbers CCDC 2047141-2. Copies of the data can be obtained free of charge from www.ccdc.cam.ac.uk/data_request/cif. 
Table S2: Crystallographic data and structure refinement details for compounds $\mathbf{5 f}$ and $\mathbf{8 a}$.

\begin{tabular}{|c|c|c|}
\hline Compound & $5 f$ & $\mathbf{8 a}$ \\
\hline CCDC number & 2047141 & 2047142 \\
\hline Formula & $\mathrm{C}_{30} \mathrm{H}_{26} \mathrm{~B}_{2} \mathrm{~F}_{4} \mathrm{~N}_{4}$ & $\mathrm{C}_{19} \mathrm{H}_{16} \mathrm{~B}_{2} \mathrm{~F}_{4} \mathrm{~N}_{4}$ \\
\hline$M_{\mathrm{r}}$ & 468.11 & 397.98 \\
\hline $\begin{array}{l}\text { Cryst. size } \\
\text { (mm) }\end{array}$ & $0.2 \times 0.15 \times 0.08$ & $0.2 \times 0.15 \times 0.08$ \\
\hline Crystal system & triclinic & triclinic \\
\hline Space group & $P(-1)$ & $P 1$ \\
\hline $\begin{array}{c}\text { Temperature } \\
\left({ }^{\circ} \mathrm{C}\right)\end{array}$ & -173 & -173 \\
\hline$a(\AA)$ & $8.9527(2)$ & $7.8604(5)$ \\
\hline$b(\AA)$ & $11.4590(3)$ & $10.9975(6)$ \\
\hline$c(\AA)$ & $12.3461(4)$ & $11.8617(6)$ \\
\hline$\alpha\left(^{\circ}\right)$ & $64.481(3)$ & $63.403(5)$ \\
\hline$\beta\left(^{\circ}\right)$ & $82.718(2)$ & $89.660(5)$ \\
\hline$\gamma\left({ }^{\circ}\right)$ & $77.051(2)$ & $70.625(6)$ \\
\hline$V\left(\AA^{3}\right)$ & 1113.29 & 852.51 \\
\hline Z & 2 & 2 \\
\hline$D_{\mathrm{x}}\left(\mathrm{Mg} \mathrm{m}^{-3}\right)$ & 1.396 & 1.550 \\
\hline$\lambda(\AA)$ & 0.71073 & 0.71073 \\
\hline$\mu\left(\mathrm{mm}^{-1}\right)$ & 0.11 & 0.12 \\
\hline Transmissions & $0.949-1.000$ & $0.792-1.000$ \\
\hline$F(000)$ & 488 & 408 \\
\hline $2 \theta_{\max }$ & 71.8 & 66.2 \\
\hline Refl. measured & 106038 & 78435 \\
\hline Refl. indep. & 9822 & 12987 \\
\hline$R_{\mathrm{int}}$ & 0.028 & 0.038 \\
\hline Parameters & 313 & 528 \\
\hline Restraints & 0 & 3 \\
\hline$w R\left(F^{2}\right.$, all refl. $)$ & 0.104 & 0.112 \\
\hline$R(F,>4 \sigma(F))$ & 0.035 & 0.042 \\
\hline $\begin{array}{c}\text { Flack } \\
\text { parameter }\end{array}$ & - & $0.3(4)$ \\
\hline$S$ & 1.06 & 1.03 \\
\hline $\operatorname{Max} . \Delta p\left(\mathrm{e} \AA^{-3}\right)$ & $0.59,-0.25$ & $0.63,-0.29$ \\
\hline
\end{tabular}


Thermal ellipsoid plots (at the $50 \%$ probability level):

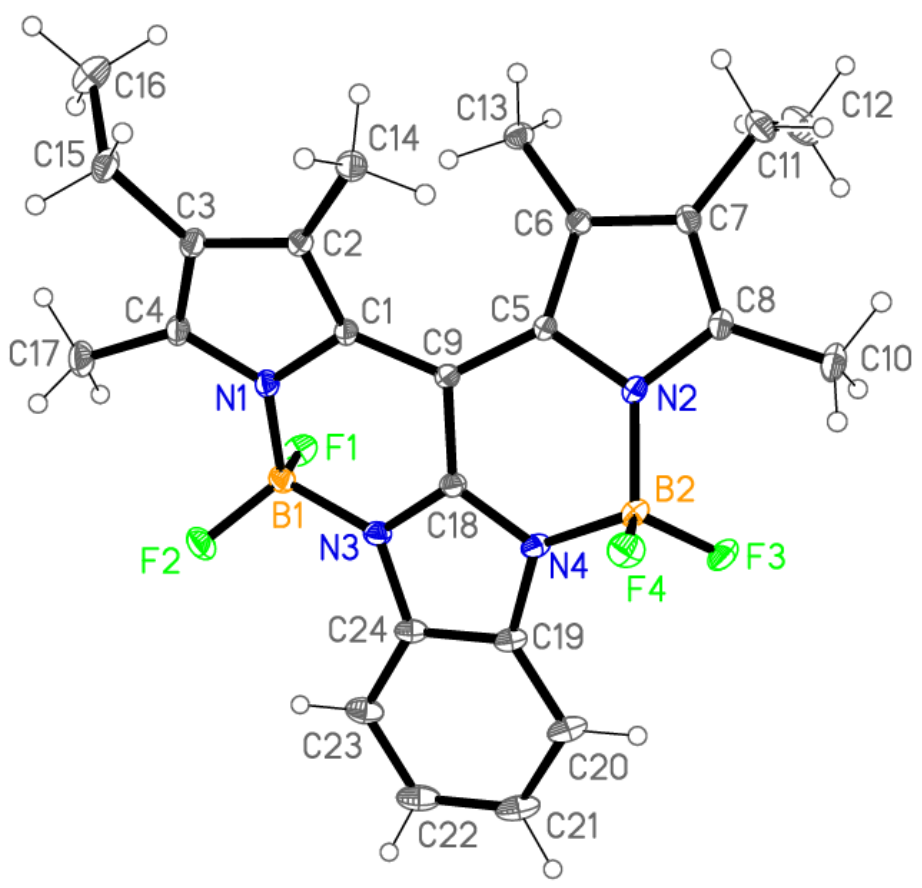

Figure S41. Structure of compound $\mathbf{5 f}$ in the crystal.

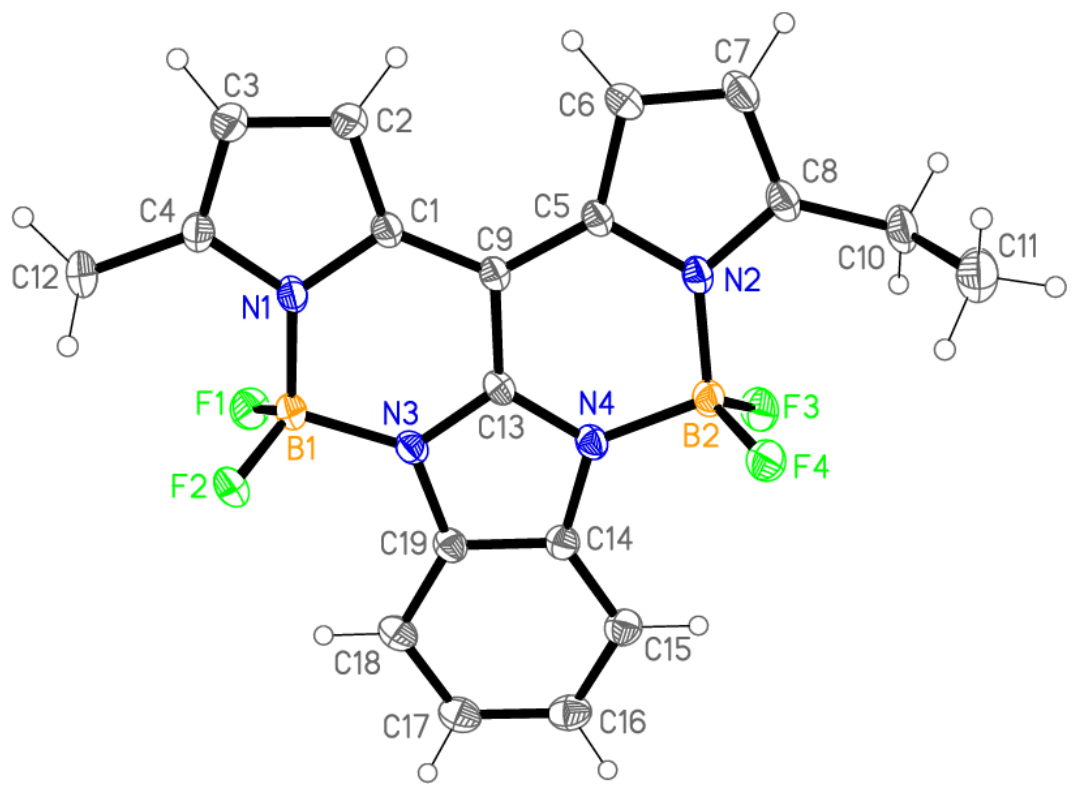

Figure S42. Structure of compound $\mathbf{8 a}$ in the crystal. The asymmetric unit consists of two independent molecules, only one of which is shown. 
(1) Patalag, L. J.; Jones, P. G.; Werz, D. B. BOIMPYs: Rapid Access to a Family of RedEmissive Fluorophores and NIR Dyes. Angew. Chem. Int. Ed. 2016, 55, 13340.

(2) Copeland, R. A. B.; Day, A. R. The Preparation and Reactions of 2Benzimidazolecarboxylic Acid and 2-Benzimidazoleacetic Acid. J. Am. Chem. Soc. 1943, 65, 1072.

(3) G. M. Sheldrick, Acta Cryst. 2015, C71, 3. 